Prepared in cooperation with the City of Longmont

\title{
Aquatic Communities and Selected Water Chemistry in St. Vrain Creek near the City of Longmont, Colorado, Wastewater-Treatment Plant, 2005 and 2006
}

Data Series 253

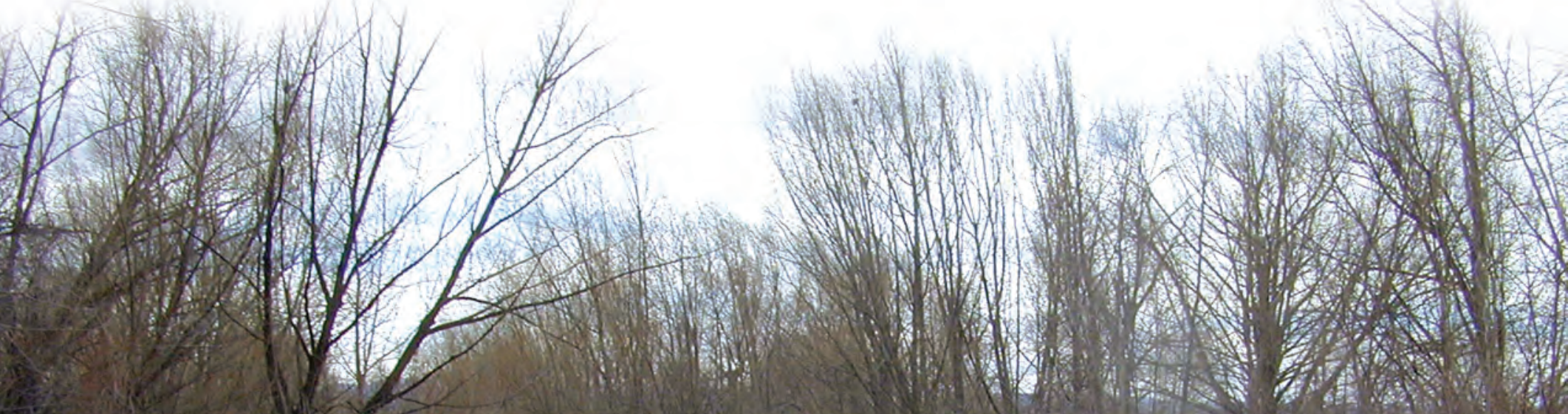

U.S. Department of the linterfor U.S. Geological Survey 
Front cover photograph: St. Vrain River downstream from Airport Road at Golden Ponds Nature Area, Longmont Colorado, late April 2005. 


\section{Aquatic Communities and Selected Water Chemistry in St. Vrain Creek near the City of Longmont, Colorado, Wastewater- Treatment Plant, 2005 and 2006}

By Robert E. Zuellig, Lori A. Sprague, Jim A. Collins, and Oliver N. Cox

Prepared in cooperation with the City of Longmont

Data Series 253 


\section{U.S. Department of the Interior DIRK KEMPTHORNE, Secretary}

\section{U.S. Geological Survey \\ Mark D. Myers, Director}

\section{U.S. Geological Survey, Reston, Virginia: 2007}

For product and ordering information:

World Wide Web: http://www.usgs.gov/pubprod

Telephone: 1-888-ASK-USGS

For more information on the USGS — the Federal source for science about the Earth, its natural and living resources, natural hazards, and the environment:

World Wide Web: http://www.usgs.gov

Telephone: 1-888-ASK-USGS

Any use of trade, product, or firm names is for descriptive purposes only and does not imply endorsement by the U.S. Government.

Although this report is in the public domain, permission must be secured from the individual copyright owners to reproduce any copyrighted materials contained within this report.

Suggested citation:

Zuellig, R.E., Sprague, L.A., Collins, J.A., and Cox, 0.N., 2007, Aquatic communities and selected water chemistry in St. Vrain Creek near the City of Longmont, Colorado, wastewater-treatment plant, 2005 and 2006: U.S. Geological Survey Data Series 253, 30 p. 


\section{Contents}

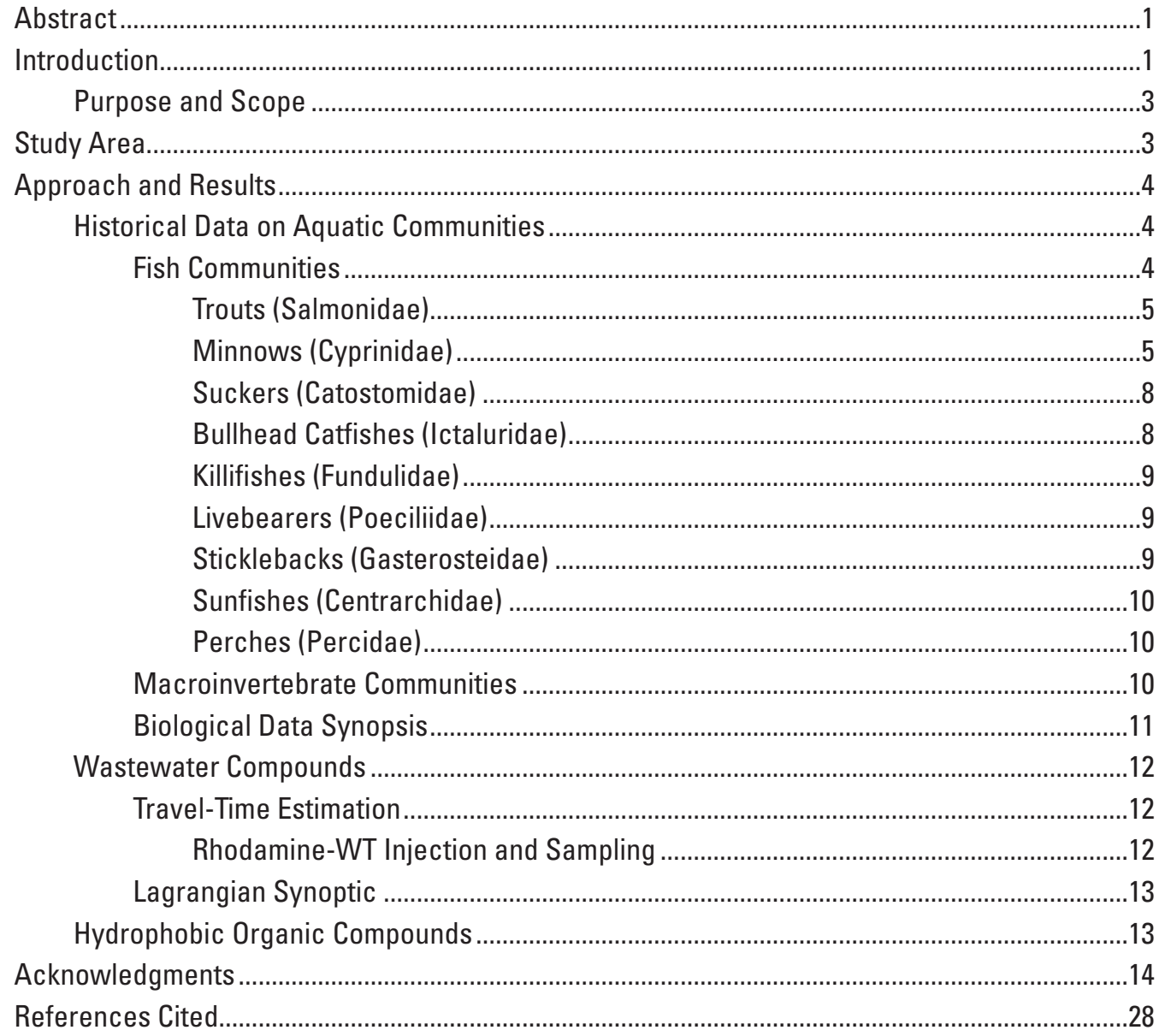

\section{Figure}

1. Map showing St. Vrain Creek Basin, Colorado, with land use, designated stream segments, and sampling stations.

\section{Tables}

1. Sites sampled for water chemistry in the study reach in Longmont, Colorado .................3

2. Travel-time results for the April 5, 2005, tracer study, St. Vrain Creek ..........................13

3. Travel-time results for the March 14, 2006, tracer study, St. Vrain Creek........................14

4. Data from the analysis of wastewater compounds and associated field properties .....15

5. Percent difference between environmental and replicate samples and percent recovery of spike concentrations of wastewater compounds .........................................25

6. Data from the toxicity assays conducted on dialysates from the semipermeable membrane devices 


\section{Conversion Factors, Datums, and Acronyms}

\begin{tabular}{lcl}
\hline Multiply & By & \multicolumn{1}{c}{ To obtain } \\
\hline & Length & \\
\hline inch (in.) & 25.4 & millimeter $(\mathrm{mm})$ \\
foot (ft) & 0.3048 & meter $(\mathrm{m})$ \\
mile (mi) & 1.609 & kilometer $(\mathrm{km})$ \\
\hline & Flow rate & \\
\hline cubic foot per second $\left(\mathrm{ft}^{3} / \mathrm{s}\right)$ & 0.02832 & cubic meter per second $\left(\mathrm{m}^{3} / \mathrm{s}\right)$ \\
\hline
\end{tabular}

Temperature in degrees Celsius $\left({ }^{\circ} \mathrm{C}\right)$ may be converted to degrees Fahrenheit $\left({ }^{\circ} \mathrm{F}\right)$ as follows:

$$
{ }^{\circ} \mathrm{F}=\left(1.8 x^{\circ} \mathrm{C}\right)+32
$$

Vertical coordinate information is referenced to the North American Vertical Datum of 1988 (NAVD 88).

Horizontal coordinate information is referenced to the North American Datum of 1983 (NAD 83).

Altitude, as used in this report, refers to distance above the vertical datum.

Specific conductance is given in microsiemens per centimeter at 25 degrees Celsius $(\mu \mathrm{S} / \mathrm{cm}$ at $\left.25^{\circ} \mathrm{C}\right)$.

Concentrations of chemical constituents in water are given either in milligrams per liter (mg/L) or micrograms per liter $(\mu \mathrm{g} / \mathrm{L})$.

\section{Acronyms}

USGS U.S. Geological Survey

SPMDs semipermeable membrane devices

AhR aryl hydrocarbon receptor

PAHs polycyclic aromatic hydrocarbons

PCBs polychlorinated biphenyls

WWTP wastewater-treatment plant

CDOW Colorado Division of Wildlife

INHS Illinois Natural History Survey

LFL Larval Fish Laboratory, Colorado State University, Fort Collins, Colorado

TEQs toxic equivalents 


\title{
Aquatic Communities and Selected Water Chemistry in St. Vrain Creek near the City of Longmont, Colorado, Wastewater-Treatment Plant, 2005 and 2006
}

\author{
By Robert E. Zuellig, Lori A. Sprague, Jim A. Collins, and Oliver N. Cox
}

\begin{abstract}
In 2005, the U.S. Geological Survey and the City of Longmont, Colo., began a study to document chemical characteristics of St. Vrain Creek that had previously been unavailable either due to high cost of analysis or lack of analytical capability. Stream samples were collected at seven sites on St. Vrain Creek during the spring of 2005 and 2006 for analysis of wastewater compounds. A Lagrangian-sampling design was followed during each sampling event, and time-oftravel studies were conducted just prior to each sampling event to determine appropriate sampling times for the synoptic. In addition, semipermeable membrane devices, passive samplers that concentrate hydrophobic organic chemicals, were installed at six sites during the spring of 2005 and 2006 for approximately 4 weeks. After retrieval, contaminant residues concentrated in the semipermeable membrane devices were recovered and used in a toxicity assay that provided a screen for aryl hydrocarbon receptor type compounds, including polycyclic aromatic hydrocarbons, polychlorinated biphenyls, dioxins, and furans.

In addition, the U.S. Geological Survey summarized information on macroinvertebrate and fish communities known from St. Vrain Creek dating back to the early 1900s in order to assess their utility in evaluating wastewater-treatment plant upgrades and habitat improvement projects. Unfortunately, because of inconsistencies in data collection these data cannot be used as intended; however, they are useful for understanding to some degree gross patterns in fish species distribution, but less so for macroinvertebrates.
\end{abstract}

\section{Introduction}

The St. Vrain Creek Basin in northeastern Colorado (fig. 1) has experienced rapid urban growth over the last two decades. As a result, some agricultural land in the lower half of the basin has been converted to urban land to accommodate the growing population in and around the cities of Longmont and Boulder. This population growth has led to an increase in treated waste volumes being processed at the wastewater-treatment plants (WWTPs) in the basin. In the last two decades, in-stream restoration efforts and new waste treatment technologies have been implemented by the City of Longmont, with the goal of improving water quality and aquatic organism community structure downstream from WWTP effluent.

WWTP upgrades primarily were designed to address conventional issues such as elevated nutrients, metals, and suspended-solids concentrations. The Longmont WWTP has been monitoring these compounds regularly to determine the efficacy of plant upgrades in decreasing concentrations in the effluent. However, recent studies have indicated that additional, previously unmonitored compounds are present in surface water downstream from WWTPs (Kolpin and others, 2002). These organic wastewater chemicals, which include detergents, disinfectants, fragrances, fire retardants, nonprescription drugs, and pesticides, can be released to the environment through discharges from industrial facilities, animal feed lots, WWTPs, and individual septic disposal systems, or through runoff from land applications in agricultural and urban areas. Some of these chemicals have been shown to disrupt endocrine systems in fish (Thorpe and others, 2001; Schreurs and others, 2004), increase antibiotic resistance of bacteria (McMurry and others, 1998), and shift the community structure of algae (Wilson and others, 2003). In addition to human waste, the Longmont WWTP also receives industrial waste from poultry and dairy operations and biotechnology and metals processing facilities; as a result, it is probable that some of these wastewater chemicals are present in St. Vrain Creek. As there is currently no information on the presence of such compounds in the Longmont WWTP effluent or in St. Vrain Creek, it is difficult to begin to assess their potential impacts on aquatic communities in the stream.

Another class of compounds that may be present in the Longmont WWTP effluent and in surface runoff from the surrounding urban areas both up and downstream from the WWTP discharge location are hydrophobic contaminants such as polychlorinated dioxins and furans, polycyclic aromatic hydrocarbons (PAHs), polychlorinated biphenyls (PCBs), organochlorine insecticides, and pyrethroid insecticides. Many 


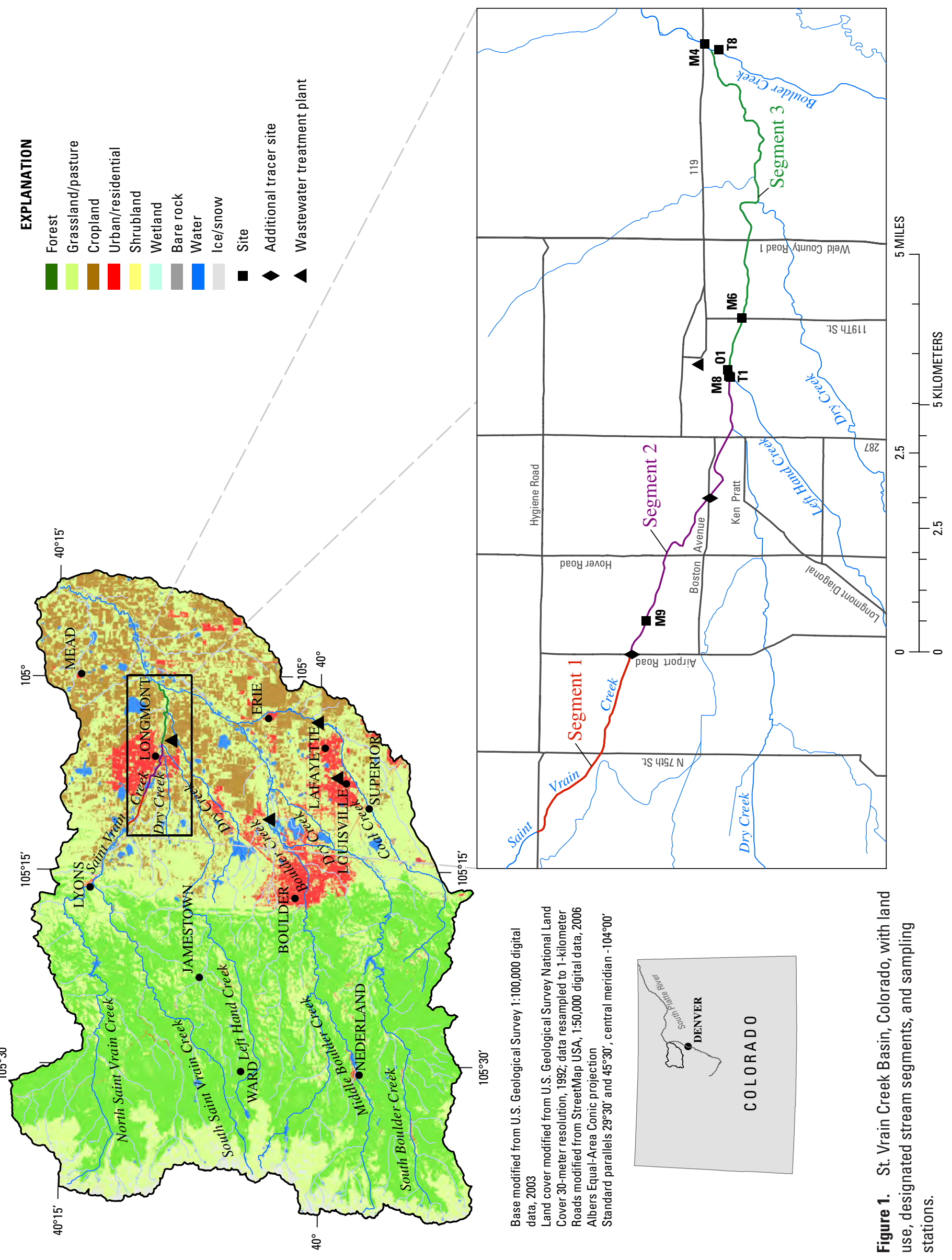


of these compounds have been shown to be toxic to aquatic organisms. However, they are not routinely monitored by the Longmont WWTP owing to the high cost of laboratory analysis and the difficulty in detecting them at their typically low concentrations. Even at low concentrations, these compounds may still be bioaccumulated by aquatic organisms. Semipermeable membrane devices (SPMDs), passive samplers that are designed to mimic the bioaccumulation of organic contaminants in the fatty tissues of aquatic organisms, concentrate trace levels of hydrophobic organic contaminants in aquatic systems over time (Huckins and others, 1990). Extracts from the sequestering media in the SPMD can be used in toxicity tests that provide a relatively inexpensive means of assessing potential toxicity at a particular location in the stream.

In 2005, the U.S. Geological Survey (USGS), in cooperation with the City of Longmont, began a study to document selected chemical characteristics of St. Vrain Creek that had previously been unavailable either due to high cost of analysis or lack of analytical capability. In addition, the USGS summarized information on macroinvertebrate and fish communities known from St. Vrain Creek dating back to the early 1900s. These historical biological data were summarized to assess their utility in evaluating WWTP upgrades and habitat improvement projects facilitated by the City of Longmont.

\section{Purpose and Scope}

This report describes results from a study whose objectives were to (1) review and summarize available information regarding fish and macroinvertebrate communities in St. Vrain Creek below Hygiene Road in Longmont to the confluence with Boulder Creek, and (2) supplement the current monitoring program in place at the Longmont WWTP with an assessment of additional chemical factors that may be affecting biological communities.

Sampling during the study included wastewater chemicals and toxicity of hydrophobic organic contaminants. St. Vrain Creek was sampled along an 8.6 mile reach beginning a few miles upstream from the WWTP outfall and ending at the confluence with Boulder Creek. Additionally, macroinvertebrate samples were collected in April of 2005 and 2006 at selected sites within the study reach and delivered to the City of Longmont where they worked with a local consulting company to process the samples.

\section{Study Area}

St. Vrain Creek originates along the Continental Divide in northeastern Colo. (fig. 1). The headwater streams travel through primarily forested land until they exit the mountains and converge near Lyons, Colo., to form St. Vrain Creek (Litke and Kimbrough, 1998). The St. Vrain then travels east through primarily agricultural land to the city of Longmont. After flowing through Longmont, the St. Vrain continues east through agricultural land to its confluence with the South Platte River near Platteville, Colo., approximately 15 miles away.

Water chemistry sampling for this study was conducted at seven sites along the study reach (table 1). Two sites were on St. Vrain Creek upstream from the WWTP outfall (M9 and M8); two sites were at the mouths of the major tributaries, Left Hand Creek and Boulder Creek (T1 and T8); one site was at the WWTP outfall (O1), and two sites were on St. Vrain Creek downstream from the outfall (M6 and M4). Site M9, located at Airport Road on the western edge of Longmont, represented inputs to St. Vrain Creek upstream from most of the urbanizing area in and around Longmont. Site M8, located immediately upstream from the WWTP outfall, represented inputs from upstream urban and agricultural inputs prior to the input of treated WWTP effluent. Site T1 was located at the mouth of Left Hand Creek and site T8 was located at the mouth of Boulder Creek; these are the two largest tributaries entering St. Vrain Creek in the study reach. Site M6 was located approximately 1 mile downstream from the outfall with no intervening tributaries, and site M4 was located just downstream from the confluence of St. Vrain Creek and Boulder Creek (previous sampling by the City of Longmont at

Table 1. Sites sampled for water chemistry in the study reach in Longmont, Colorado.

[Abbreviation: USGS, U.S. Geological Survey]

\begin{tabular}{lcl}
\hline Site number $^{1}$ & USGS station number & \multicolumn{1}{c}{ Site name } \\
\hline M9 & 401011105084701 & St. Vrain Creek below Airport Road at Longmont \\
M8 & 400919105051501 & St. Vrain Creek 50 feet above Left Hand Creek at Longmont \\
T1 & 400918105051601 & Left Hand Creek 30 feet above mouth at Longmont \\
O1 & 400920105051001 & Wastewater outflow on St. Vrain Creek at Longmont \\
M6 & 400911105042500 & St. Vrain Creek at North 119th Street near Longmont \\
T8 & 400928105003401 & Boulder Creek 400 feet above mouth at Longmont \\
M4 & 400937105002901 & St. Vrain Creek at Highway 119 near Longmont \\
\hline
\end{tabular}

${ }^{1}$ Location of sites shown in figure 1. 
site M4 was upstream from the Boulder Creek confluence). Due to the limited scope of the study, all tributaries and storm drains along the study reach were not sampled.

\section{Approach and Results}

\section{Historical Data on Aquatic Communities}

Available information on macroinvertebrate and fish communities was reviewed from previously published literature, the Colorado Division of Wildlife (CDOW) fish database, and from holdings at the Illinois Natural History Survey (INHS) in Urbana, Illinois, and the C.P. Gillette Museum of Arthropod Diversity at Colorado State University in Fort Collins, Colorado. The Larval Fish Laboratory (LFL, Colorado State University, Fort Collins, Colo.) also was contacted but they did not have any historical records of fish from St. Vrain Creek in their holdings. An exhaustive search of additional museums was not made because much of this historical information was previously incorporated in the literature and the CDOW fish database. Additional records of fish from St. Vrain Creek may exist in other museum holdings but likely do not include new species records for this drainage. Although a comprehensive knowledge of aquatic community structure prior to the many hydrologic, water quality, and habitat alterations made to St. Vrain Creek is unavailable, much more is known about fish than macroinvertebrates.

\section{Fish Communities}

The first known fish collections from the plains portion of St. Vrain Creek did not take place until the early 1900s (Juday, 1904, 1905). Although these collections took place more than 100 years ago, they occurred well after many alterations in hydrology, water quality, and habitat had occurred in the area (Fausch and Bestgen, 1996). Because of the lack of information prior to these alterations, it is difficult to get a clear picture of historical fish distribution and abundance patterns in St. Vrain Creek prior to 1900. Information on early fish distribution patterns in Boulder County is available primarily as a result of the early collections by Juday (1904, 1905) from Boulder and St. Vrain Creeks. Ellis (1914) was the first to publish a comprehensive recollection of the fishes of Colorado, which included collections from 1912 and 1913, earlier published accounts, and holdings at the University of Colorado at Boulder including those of Juday $(1904,1905)$. Hendricks (1950) later summarized his and the early collections of fishes from Boulder County prior to 1950, providing additional knowledge about fish community structure in the lower St. Vrain and Boulder Creeks. Hendricks noted that several species had been eliminated based on his collections by that time. In 1952, Beckman published a guide to the fishes of Colorado, providing a taxonomic key for identification but did not include specific collection locality information.
Later, Li (1968) described the early surveys of the South Platte River Basin, including the early work in St. Vrain Creek, and reconciled some of the probable misidentifications and nomenclature changes in the historic record. During the early 1970s local consultants and Colorado State University graduate students conducted several surveys to assess the influence of the Fort St. Vrain power plant operations on biological communities near the confluence of St. Vrain Creek and South Platte River (downstream from the study reach). Propst (1982) further sorted out historical accounts and led a major effort to describe the distribution, ecology, and community dynamics of fishes of the plains portion of the South Platte River Basin (Propst and Carlson 1986). Propst's work included sampling St. Vrain Creek in the late 1970s. Several collections have occurred since that time that were part of comprehensive inventories of the South Platte River system (Nesler and others, 1997), were sporadic collections that provided little comprehensive information (unpublished data in CDOW fish database), or were not available for review (data from Schrader, 1989).

Few direct comparisons of site-specific species abundance or richness can be made using the assembled fish data from St. Vrain Creek because of the variety of methods used, the variability in space and time of sampling, the unknown level of reliability associated with each collection, and the uncertainty around the consistency of species reported during earlier sampling. For example, some records in the CDOW fish database reported only one species for a sampling event when certainly more were present. Additionally, notes in the database were unfortunately often incomplete and included very little information on capturing methods and amount of effort used prior to the data collected by Nesler and others (1997). Furthermore, there was very little consistency regarding which sites were sampled across seasons and years. Although these data may not be useful for assessing sitespecific trends in abundance and richness in St. Vrain Creek, they are useful for understanding to some degree gross patterns in species distribution along the entire study reach. Because of the sporadic nature of collections at various sites and times, species occurrences are described by distinct segments as follows: segment 1 includes sites from Airport Road upstream to Hygiene Road, segment 2 includes sites from Airport Road downstream to the WWTP, and segment 3 includes sites from the WWTP downstream to Boulder Creek.

Below is a brief summary of the known distribution and historic accounts of fishes found in lower St. Vrain Creek from Hygiene Road downstream to the confluence with Boulder Creek. Much of this historic information regarding the occurrence of fish species in St. Vrain Creek has been previously summarized by earlier workers as part of larger scale studies such as investigations of the fishes of Boulder County (Juday, 1904, 1905; Hendricks, 1950), the South Platte River Basin in Colorado (Li, 1968, Propst, 1982; Propst and Carlson, 1986; Nesler and others, 1997), the Great Plains portion of Colorado (Fausch and Bestgen, 1996), and of Colorado (Ellis, 1914; Beckman, 1952; Woodling, 1985). Species accounts 
and information from the above publications and other sources mentioned earlier are summarized by the first known collection records of the species from St. Vrain Creek, generalizations about which river segment a species occurred in, brief notes on habitat and spawning requirements, and species status in Colorado and elsewhere when applicable.

\section{Trouts (Salmonidae)}

Various non-native trout species are routinely stocked in gravel pits and reservoirs in the upper reaches of the plains portion of St. Vrain Creek near the plains-mountain interface for recreational opportunities, but only one species, brown trout (Salmo trutta), has been reported from the study reach (CDOW fish database). Brown trout are consistently collected in low numbers upstream from Hover Road and become more abundant in samples closer to the plains-mountain interface. Occasionally, brown trout are collected below Hover Road. Historically, native greenback cutthroat trout (Oncorhynchus clarki stomias) likely inhabited the uppermost reaches of the plains portion of St. Vrain Creek (Behnke, 1992) and possibly through the study reach, especially during high snowmelt runoff years. Historical overfishing and especially the introduction of other salmonids are apparent causes of greenback cutthroat disappearance across its native South Platte range (Behnke, 1992). Potentially increased water temperatures associated with water withdrawal for irrigation purposes near the plains-mountain interface possibly further influenced downstream fish communities. Greenback cutthroat trout was federally listed as endangered in 1973. Since that time, several locations in the headwaters of St. Vrain Creek Basin have been used as reintroduction sites as part of the recovery plan for this federally listed species. Currently, greenback cutthroat trout is federally and state listed as threatened (Schmidt, 2006). There are no known records of this species from the study reach.

\section{Minnows (Cyprinidae)}

Central stoneroller (Campostoma anomalum) is considered common in the South Platte River system (Nesler and others, 1997). When present, it is usually not a dominant component of total fish abundance (Propst, 1982). It inhabits foothill streams to the lower reaches of the South Platte River but is usually not found in reaches influenced by organic enrichment (Woodling, 1985). Typical habitat requirements include sand-gravel-bottomed pools and riffles with some current. In Missouri, this species requires streams with permanent flow and well-defined riffles with gravel, rubble, or bedrock substrate (Pflieger, 1997). This species has specialized mouthparts to feed on algae but also intakes midge larva, some plant tissue, sand, and clay (Schrader, 1989 and citations within). Clean gravel, moderately clear water, and a nearby pool are requirements for spawning (Schrader, 1989 and citations within; Cross and Collins, 1995). Juday (1905) first reported central stoneroller from the lower St. Vrain River at a site presumably near Highway 287 (segment 2). This species is consistently collected at sites upstream from the WWTP (segments 1 and 2) and occasionally downstream in segment 3 (CDOW fish database). This species is listed as a species of concern in North Dakota (Schmidt, 2006).

Native to eastern Asia, goldfish (Carassius auratus) was introduced into Colorado in the 1870s (Wiltzius, 1981). When present, goldfish never make up a large portion of the fish community in terms of abundance in stream habitats in Colorado (CDOW fish database). Goldfish have been occasionally collected in St. Vrain Creek probably as a result of well-meaning people releasing their unwanted pets. The influence of goldfish on plains fish communities is unknown but is probably minimal because they are rarely collected in stream systems. The earliest records of goldfish in St. Vrain Creek are from the early 1900s as reported by Juday (1905).

Lake chub (Couesius plumbeus) was considered extirpated from the South Platte River Basin (Propst, 1982) until a single specimen was collected from South Fork St. Vrain Creek upstream of Lyons in 1989 (Bestgen and others, 1991). Since that time it has been collected from reservoirs in the upper Poudre River and Clear Creek Basins (Nesler and others, 1997; Kevin Bestgen, Larval Fish Laboratory, Colorado State University, oral commun., 2006) and recently from a private reservoir on Middle Fork St. Vrain Creek and from Barker Reservoir in Nederland (Harry Crockett, Colorado Division of Wildlife, oral commun., 2006). Historical records from the early 1900s are from St. Vrain and Boulder Creeks (Juday, 1904, 1905; Ellis, 1914; Bestgen and others, 1991; Nesler and others, 1997). Adults are primarily insectivores and have generalized spawning requirements (Schrader, 1989 and citations within). Lake chub is state listed as endangered in Colorado and Massachusetts and is a species of concern in Illinois, North Dakota, Washington, and Wyoming (Nesler and others, 1997; Patton, 1997; Schmidt, 2006). Currently, this species appears to be limited to upper-elevation lakes and reservoirs with rocky shorelines. Most recent records are from lake habitats with rocky shorelines, whereas historical records are primarily from transition zone stream habitats. In Wyoming, lake chub is found in a variety of habitats including both small streams and lakes (Baxter and Stone, 1995). More effort is needed to better understand its distribution in Colorado and in the St. Vrain Basin (Nesler and others, 1997).

Red shiner (Cyprinella lutrensis) is considered common in the South Platte River system (Nesler and others, 1997) and is tolerant of many natural variations in physical and chemical conditions (Propst, 1982). It is typically associated with eddies formed by trees, debris piles, and riprap as well as large pools and is most common in the lower reaches of the South Platte River and its tributaries (Propst, 1982). Red shiner is considered an opportunistic feeder that primarily feeds on insects (Pflieger, 1997) and has generalized spawning requirements (Schrader, 1989 and citations within). The earliest records of this species in St. Vrain Creek are from the collections of Juday made in the early 1900s (Ellis, 1914). Red shiner has been collected both upstream and downstream from the WWTP (segments 1, 2, and 3) but is more consistently collected in segment 3 (CDOW fish database). 
Native to Europe, common carp (Cyprinus carpio) was introduced into Colorado in 1879 (Wiltzius, 1981) and since has been found in most warm water river systems and reservoirs in the State (Woodling, 1985). This species tolerates a wide variety of environmental conditions, including organically enriched water below wastewater and industrial effluents. Large schools of feeding carp can disrupt the spawning of other species and increase turbidity in shallow water systems (Woodling, 1985). In St. Vrain Creek, carp are commonly collected in segments 2 and 3 in the study reach (CDOW fish database). The influence of this species on native plains fish in Colorado is unknown.

Brassy minnow (Hybognathus hankinsoni) was once considered common in the South Platte River Basin (Ellis, 1914); however, its distribution has been significantly reduced in Colorado (Propst, 1982; Nesler and others, 1997). Brassy minnow is tolerant of a wide range of physical and biological conditions associated with harsh plains environments. This species mostly consumes algae but also feeds on zooplankton, phytoplankton, aquatic insects, and plants and requires aquatic vegetation for spawning (Schrader, 1989 and citations within). The decline of brassy minnow is assumed to be a result of habitat reduction and possibly poor water quality. Slowmoving pools and flooded backwater habitats are important for the persistence of this species. In the Arikaree River in eastern Colorado, basin-wide movements were required by brassy minnow in order to move between spawning, rearing, and over-summering and over-wintering habitat (Scheurer and Fausch, 2003). In the plains portion of St. Vrain Creek, brassy minnow is occasionally collected both upstream and downstream from the WWTP (CDOW fish database). Brassy minnow is state listed as threatened in Colorado and is currently listed as rare, a species of special concern, or is a candidate species for listing in Illinois, Kansas, Missouri, Vermont, British Columbia, and Quebec (Nesler and others, 1997; Schmidt, 2006). The plains portion of St. Vrain Creek is vital to the persistence of brassy minnow in transition zone stream habitats in the South Platte River Basin. More work is warranted in these habitats to better understand requirements of brassy minnow occurrence in transition zone streams.

Common shiner (Luxilus cornutus) distribution is localized in the South Platte River Basin, found mainly in St. Vrain Creek and the Upper South Platte tributary system (Nesler and others, 1997). Generally, this species requires streams with moderate gradient and cool, clear water, and silt-free gravel, overhung by riparian vegetation. Common shiner is apparently sensitive to habitat changes due to siltation events (Nesler and others, 1997). Diet consists of algae, aquatic plants, and aquatic insects (Schrader, 1989 and citations within). Common shiner generally spawns in moving water over gravel or rubble and is known to use spawning nests of other species such as creek chub or hornyhead chub (Cross and Collins, 1995). Earliest collection records in St. Vrain Creek are from the early 1900s, presumably upstream from the WWTP in segment 2 (Juday, 1905). In St. Vrain Creek, common shiner is routinely collected from all stream segments but is most consistently found upstream from the WWTP in segments 1 and 2 (CDOW fish database). Efforts have been made by the CDOW to enhance current populations of common shiner in the St. Vrain Basin by selective stocking (Randy Van Buren, Colorado Division of Wildlife, oral commun., 2005). Currently, common shiner is state listed as threatened due to its decline in distribution and abundance in Colorado and is a species of concern in Wyoming (Nesler and others, 1997; Schmidt, 2006). In Colorado, most of the decline on record has occurred since the late 1970s (Nesler and others, 1997). The lower St. Vrain and tributaries are critical for the consistent well-being of this species in transition-zone stream habitats in Colorado. More work is warranted in the St. Vrain Basin to better understand requirements for common shiner persistence.

Hornyhead chub (Nocomis biguttatus) was historically reported from Boulder and St. Vrain Creeks in the early 1900s (Juday, 1905). No other collections of this species have been made in Colorado since the early records of Juday (Ellis, 1914; Hendricks, 1950; Li, 1968; Propst, 1982; Nesler and others, 1997). Hornyhead chub builds a mound of clean gravel in which to spawn (Cross and Collins, 1995). Several other species have been observed using chub mounds as spawning sites (Pflieger, 1997). Diet primarily consists of insects (Cross and Collins, 1995). Hornyhead chub is considered extirpated from Colorado (Nesler and others, 1997) and has noticeably declined in Wyoming where it was historically common in the Laramie River system (Baxter and Stone, 1995). Populations have also disappeared from western Kansas (Cross and Collins, 1995), where it is state listed as threatened (Schmidt, 2006), and from the prairie portion of some Missouri streams (Pflieger, 1997). Additionally, hornyhead chub is a species of concern in North Dakota, Pennsylvania, and Manitoba (Schmidt, 2006).

Bigmouth shiner (Notropis dorsalis) inhabits the lower portions of the South Platte River and its major tributaries (Propst, 1982). Its distribution is patchy owing to specific habitat requirements such as sand and gravel-bottomed runs and riffles. This species appears to be intolerant of nutrient enrichment (Propst, 1982) and feeds on both invertebrates and filamentous algae (Schrader, 1989 and citations within). Although it is uncertain, bigmouth shiner is thought to spawn in open water as some other members of the genus where semi-buoyant eggs hatch as they drift downstream (Moore, 1944). In the CDOW fish database, bigmouth shiner was present in collections from the 1960s to the 1990s in lower St. Vrain Creek. In the 1960s, 1970s, and 1980s, bigmouth shiner was collected from stations both up and downstream from the WWTP (segments 1, 2, and 3). Since 1990, it has only been collected one time out of eight sampling events at a station near Highway 287 (segment 2) and was not present in any of three sampling events downstream from the WWTP (CDOW fish database). Similar patterns in bigmouth shiner absence from previous collection locations have been observed in the Big Thompson and Cache la Poudre Rivers since the 1980s (Kevin Bestgen, Larval Fish Laboratory, Colorado State University, oral commun., 2006). More effort is warranted to 
better understand bigmouth shiner distribution and abundance in St. Vrain Creek. Bigmouth shiner is listed as a species of concern in Indiana, Tennessee, and Manitoba, and is considered threatened in Pennsylvania (Schmidt, 2006).

Juday (1905) first reported blacknose shiner (Notropis heterolepis) in Colorado from St. Vrain Creek in Longmont. Propst (1982) believed the records to be authentic; however, this species has never been recollected in Colorado and consequently is considered extirpated from the State (Nesler and others, 1997). Additionally, blacknose shiner has been extirpated from Kansas (Cross and Collins, 1995) and from several streams in Missouri (Pflieger, 1997). Diet primarily consists of insects and small crustaceans (Becker, 1983), and spawning requirements are currently unknown. Additionally, this species is endangered in Illinois, Nevada, Ohio, and South Dakota, threatened in Iowa, and is a species of concern in North Dakota (Schmidt, 2006).

Sand shiner (Notropis stramineus) is commonly collected from the South Platte River and its major tributaries, where it often comprises a large portion of the sample when present (Propst, 1982). It inhabits a wide array of habitat types; however, it apparently avoids high-velocity riffles and deep pools. Although this species has been collected from areas with a variety of environmental conditions, it apparently is intolerant of heavy organic enrichment and silt-laden irrigation-return waters (Propst, 1982). Sand shiner feeds primarily on aquatic insects (Schrader, 1989 and citations within) and spawns over clean gravel in Missouri (Pflieger, 1997). Very little additional information is available regarding the details of spawning behavior. It is likely this species has somewhat flexible spawning requirements, as it is a common constituent of many plains streams in Colorado. In the plains portion of St. Vrain Creek, sand shiner has been routinely collected both upstream and downstream from the WWTP in all segments (CDOW fish database).

Historically, suckermouth minnow (Phenacobius mirabilis) was widespread in foothills and plains streams of the South Platte River Basin (Bestgen and others, 2003). Currently, in the South Platte River Basin, it is apparently restricted to the lower reaches (Bestgen and others, 2003; Nesler and others, 1997). Propst (1982) found this species associated with shallow side channels with sand and gravel riffles and suggested they are sensitive to siltation and nutrient enrichment. Bestgen and others (2003) found deep pools below diversion dams to be important features for suckermouth minnow during drought in the South Platte River Basin. Like Propst, Bestgen and others (2003) typically collected suckermouth minnow over gravel. They feed primarily on aquatic insects, but are known to consume plant material and bottom ooze (Schrader, 1989 and citations within). The first reported records of suckermouth minnow in St. Vrain Creek are from Juday (1905). Subsequently, this species has not been recollected in the St. Vrain system (Nesler and others, 1997) although St. Vrain Creek was not intensively sampled during a recent investigation of factors influencing suckermouth minnow distribution (Bestgen and others, 2003). Suckermouth minnow is currently listed as state endangered in Colorado and Mississippi, threatened in New Mexico, and is a species of concern in Arkansas, Louisiana, South Dakota, West Virginia, and Wyoming (Nesler and others, 1997; Schmidt, 2006). More effort is needed to identify suckermouth minnow distribution in St. Vrain Creek downstream from the WWTP.

Northern redbelly dace (Phoxinus eos) is rare in Colorado, both historically and at present (Nesler and others, 1997). Bestgen (1989) documented the distribution of this species and provided notes on its biology in Colorado. In the South Platte River system, this species was present in Boulder and St. Vrain Creeks. It is currently only present in Colorado in the Upper South Platte tributary of West Plum Creek 50 miles southwest of Denver (Bestgen, 1989). All recent records of this species in Colorado are from transition zone, standing-water habitats (Bestgen, 1989), and historical records reported by Ellis (1914) were all from transition-zone stream habitats in West Plum Creek, Boulder Creek, and St. Vrain Creek. Despite extensive sampling, this species was not collected from stream habitats but rather from cool, clear, standing water habitats off the main channel in the West Plum Creek area (Bestgen, 1989). Bestgen (1989) noted that these standing-water habitats were associated with cool springs or diverted cool-stream flow. In West Plum Creek, northern redbelly dace diet includes mostly detritus; however, they also consume plant material, algae, and zooplankton (Bestgen, 1989). Spawning apparently occurs in mats of filamentous algae (Becker, 1983). Reductions of this species in streams are presumed to be a result of the destruction of associated off-channel habitats by stream channelization, reductions in discharge, and poor water quality (Bestgen, 1989). Interestingly, a hybrid specimen ( $P$. eos $\mathrm{x}$ finescale dace [P. neogaeus]) was collected from St. Vrain Creek in 1986 upstream from the WWTP (Bestgen, 1989). Although finescale dace has never been collected in the South Platte River Basin, hybrids are maintained by gynogenesis where the hybrid dace are female clones (Dawley and others, 1987; Bestgen, 1989). In gynogenesis, genetic material is not incorporated into the offspring even though the sperm from the male is needed to stimulate egg development. Some female hybrid dace can even reproduce by cloning (Goddard and others, 1998). Schlosser and others (1998) reported entire populations with the same genes in Minnesota. Northern redbelly dace is currently state listed as endangered in Colorado, Massachusetts, threatened in Nebraska and South Dakota, and of concern in North Dakota (Nesler and others, 1997; Schmidt, 2006). Montana listed hybrid populations as species of special concern (Hunter, 1997). Protected off-channel habitats will likely be needed in the St. Vrain Creek Basin to reestablish populations. Recently, individuals were stocked in the St. Vrain Creek Basin in two small off-channel habitats on City of Boulder and Boulder County Open Space property (Harry Crockett, Colorado Division of Wildlife, oral commun., 2006). It is unknown to what extent instream habitat typical of northern redbelly dace has changed in the St. Vrain Creek and Boulder Creek Basins since early collections. 
Aquatic Communities and Selected Water Chemistry in St. Vrain Creek, near Longmont, Colorado, 2005 and 2006

Fathead minnow (Pimephales promelas) is one of the most frequently encountered species in the South Platte River Basin (Nesler and others, 1997) and can tolerate a wide variety of environmental conditions (Propst, 1982; Pflieger, 1997). Although it can make use of a variety of habitats, it is most frequently found in stream reaches with numerous pools and velocities below a few centimeters per second (Propst, 1982). Diets are composed primarily of algae and higher plant material; however, they also consume aquatic insects (Schrader, 1989 and citations within). Eggs are deposited on submerged objects such as rocks, boards, or tree roots during spawning (Markus, 1934). In the plains portion of St. Vrain Creek, they are often the most frequently encountered minnow present in samples both above and below the WWTP (CDOW fish database).

Longnose dace (Rhinichthys cataractae) is typically associated with foothill and transition-zone streams of the South Platte River Basin, inhabiting riffles with rubble substrate having moderate to fast velocity (Propst, 1982). Its abundance typically decreases as riffle habitat becomes less common. Longnose dace can tolerate a wide variety of environmental conditions, even heavy organic enrichment and heavily urbanized areas. Food items include mostly aquatic insects and small amounts of algae (Schrader, 1989 and citations within). Breeding habits have not been studied in the Rocky Mountain region (Baxter and Stone, 1995). Longnose dace also persists in low numbers in the main stem of the South Platte River in eastern Colorado (Propst, 1982). In the plains portion of St. Vrain Creek, longnose dace has been consistently collected upstream and downstream from the WWTP (CDOW fish data base).

Creek chub (Semotilus atromaculatus) is considered common in the South Platte River Basin (Propst, 1982; Nesler and others, 1997). This species can be found in all habitat types, including environmentally degraded locations; however, it prefers sites with a high degree of habitat diversity (Propst, 1982). Creek chub inhabits a variety of habitats including shallow backwaters, undercut banks retained by root systems, and deep pools. Creek chub are generalists, feeding on aquatic insects and small fishes; however, their diets shift depending on what is available (Schrader, 1989 and citations within). It is usually associated with flowing streams with gravel substrate for spawning but is more tolerant of silt than other gravel spawning fishes (Baxter and Stone, 1995). In St. Vrain Creek, creek chub is a common constituent of collections both upstream and downstream from the WWTP (CDOW fish database).

\section{Suckers (Catostomidae)}

Longnose sucker (Catostomus catostomus) is considered a common cool-water transition zone species (Nesler and others, 1997). It inhabits a variety of habitats, and is often collected from high velocity riffles, undercut banks, and shaded pools (Propst, 1982). It is usually absent from sites void of riffles or runs and is absent from intermittent streams. Longnose sucker is an opportunistic feeder, taking advantage of both plants and invertebrates (Schrader, 1989 and citations within). Prior to 1980, it was commonly collected in low numbers in the main stem of the South Platte River as far east as Julesburg (CDOW fish database). Juday (1905) reported the first known collections of longnose sucker from St. Vrain Creek, presumably collected near Highway 287 (segment 2). This species continues to be collected in all segments of the study reach.

White sucker (Catostomus commersoni) is a very prevalent species in the South Platte River Basin and can tolerate a wide variety of environmental conditions (Propst, 1982). Large white suckers (greater than 6 inches in total length) are usually found in deep pools and slow moving runs; small white suckers (less than 6 inches in total length) inhabit shallow backwater, riffles of moderate velocity, and sand-rubble runs. White suckers consume a wide range of food items including insects, plant material, fish, and fish eggs (Schrader, 1989 and citations within). Juday (1905) collected the earliest records of white sucker from St. Vrain Creek at a site presumably near Highway 287 (segment 2). Since that time, this species continues to be present in collections throughout the plains portion of St. Vrain Creek (CDOW fish database).

\section{Bullhead Catfishes (Ictaluridae)}

Black bullhead (Ictalurus melas) typically occurs in low numbers in plains streams and can tolerate a wide range of water-quality conditions (Nesler and others, 1997). Propst (1982) reported it from several "widely scattered locations" in the South Platte River Basin. When found, it often inhabits silt and sand-bottomed backwater pools or sloughs associated with gravel bars, bridge abutments, or debris piles (Propst, 1982). Immature individuals often eat crustaceans, and adults feed on large cladocerans, midge pupae, and other immature aquatic insects (Repsys and others, 1976). They often spawn in cavities in logs or undercut banks, but no overhead cover is necessary for spawning success (Pflieger, 1997). In St. Vrain Creek, black bullhead is occasionally collected from sites above and below the WWTP (CDOW fish database). Nocturnal habits likely make this species less susceptible to daytime sampling, which may help explain why they are infrequently collected.

Channel catfish (Ictalurus punctatus) has never been common in moving water habitats of the South Platte River Basin (Ellis, 1914; Li, 1968; Propst, 1982). Populations are primarily managed by stocking in reservoirs for sport fishing (Nesler and others, 1997). This species occasionally is collected from St. Vrain Creek both above and below the WWTP (CDOW fish database). The occurrence of this species in St. Vrain Creek is likely a result of escapes from adjacent abandoned gravel pits and reservoirs managed for fishing.

Stonecat (Noturus flavus) is considered rare in Colorado, having only been collected from the St. Vrain and Republican River Basins (Nesler and others, 1997). Cockerell (1908) reported stonecat from Colorado but did not provide location information. Beckman (1952) reported it from the Republican River near the Colorado-Nebraska border; however, specimens are not available for verification of these early 
reports. Cancalosi (1981) confirmed the presence of stonecat in the Republican River. No specimens were reported by Propst (1982) during an extensive inventory of the South Platte River Basin. Later, Platania and others (1986) collected stonecat from St. Vrain Creek at a site just upstream from the WWTP (segment 2). In Missouri, stonecat inhabits shallow riffles or runs with noticeable current and available cover and is apparently absent from high-velocity streams (Pflieger, 1997). Similar habitat requirements are described by Cross and Collins (1995) in Kansas. Platania (1986) reported St. Vrain Creek specimens being collected from a variety of habitats with available cover including "undercut banks" and a "shallow, unvegetated, rubble-substrate pool." Diet mainly consists of aquatic insects, but they also feed on minnows, crayfish, mollusks, and plant material (Schrader, 1989 and citations within). Large specimens occasionally eat other fish. Eggs are typically deposited under flat stones and guarded by the male. This species is likely more common than records indicate because of its nocturnal habits and preference for cover that make it less susceptible to daytime sampling (Nesler and others, 1997). Cross and Collins (1995) reported declines in stonecat distribution in western Kansas. Stonecat is endangered in North Carolina and Vermont and is a species of concern in Arkansas, Massachusetts, Oklahoma, Virginia, and Saskatchewan (Nesler and others, 1997; Schmidt, 2006). Additionally, stonecat is a species of concern in Colorado due to its limited distribution. The historic distribution, present abundance, and specific habitat requirements of stonecat in Colorado is unclear.

\section{Killifishes (Fundulidae)}

Plains topminnow (Fundulus sciadicus) is considered uncommon in the South Platte River Basin (Nesler and others, 1997). When collected, it is found almost exclusively at sites with aquatic vegetation, almost stagnant water, and gravel substrate (Propst, 1982). Diet is not well studied; however, insects are thought to be an important component (Pflieger, 1997; Cross and Collins, 1995). Eggs are deposited among plants or algae. Collection of plains topminnow from St. Vrain Creek has been rare (CDOW fish database). Juday (1905) first reported the species from the St. Vrain and Boulder Creeks. Ellis (1914) later reported several individuals from similar sites in the St. Vrain Creek Basin. Propst (1982) noted there was "no apparent geographic pattern to their distribution" and that they were "absent from many sites containing suitable habitat." Plains topminnow was last collected from St. Vrain Creek in 2004 downstream from the WWTP; prior to 2004, it was collected sporadically at sites upstream (CDOW fish database). Lynch (1988) suggested competition with mosquito fish, a widely introduced species for mosquito control, to be a reason for plains topminnow declines in Nebraska. Others have linked native species declines to mosquito fish, as it is a known predator of other fish larvae (Meffe, 1985). Nesler and others (1997) and Patton (1997) suggested this is not the case in Colorado and Wyoming. Plains topminnow is a species of concern in Missouri, Minnesota, and Oklahoma, and is threatened in South Dakota (Nesler and others, 1997; Missouri Natural Heritage Program, 2006; Schmidt, 2006).

Plains killifish (Fundulus zebrinus) is a minor component of most moving water habitats, but is a very distinctive component of plains streams. It has been reported from foothill streams, but only from sites resembling plains locations (Propst and Carlson, 1986). Typically, plains killifish is found in shallow, stagnant, backwater habitats, and other protected areas with filamentous algae (Propst, 1982). They are opportunistic feeders with a preference for aquatic insects but also eat diatoms and other plant material. Eggs are deposited on sand and are unattended (Cross and Collins, 1995). The earliest records of this species from St. Vrain Creek are from the early 1900s (Juday, 1905); there are few additional records of plains killifish from St. Vrain Creek since that time (CDOW fish database). Bestgen (Larval Fish Laboratory, Colorado State University, oral commun., 2006) has noticed declines in killifish presence from previous collection locations in the Big Thompson and Cache la Poudre Rivers since the 1980s.

\section{Livebearers (Poeciliidae)}

Non-native western mosquito fish (Gambusia affinis) was not present in records before 1980 in the South Platte River Basin (CDOW fish database) and has not received much attention in the literature of the fishes of Colorado. This fish has been widely introduced as a means to control mosquitoes in Colorado (Woodling, 1985) and others parts of the United States and the World. This species is susceptible to cold temperatures and typically does not survive winters in Colorado, although a few over-wintering populations have been found in Denver and other parts of the State (Woodling, 1985). Diet consists of aquatic insects as well as fish larvae. Young are born live and fully active, repeatedly, during the summer (Cross and Collins, 1995). Western mosquito fish can inhabit nearly all still-water habitats associated with plains streams, from slow-moving pools to isolated, stagnant overflow areas. The influence of this species on native fish requiring similar habitat such as plains killifish and plains topminnow is unknown in Colorado. In Nebraska, Lynch (1988) suggested competition with mosquito fish to be a reason for plains topminnow declines. Others have found mosquito fish to consume other fish larvae (Meffe, 1985). The influence of mosquito fish on morphologically similar native species such as plains topminnow and plains killifish in Colorado is unknown.

\section{Sticklebacks (Gasterosteidae)}

Propst and Carlson (1986) describe brook stickleback (Culaea inconstans) as a minor component of plains streams and as having a "patchy" distribution in the South Platte River Basin. Propst (1982) considered brook stickleback as native, although this species was not recorded in early surveys. This species seems to prefer undercut banks and backwater habitats with vascular macrophytes or filamentous algae (Propst, 1982). Diet includes algae, aquatic insect larvae, and small 
crustaceans (Schrader, 1989 and citations within). Nests are constructed in shallow water (Woodling, 1985). This species occasionally is collected from St. Vrain Creek at locations just upstream from the WWTP (segment 2). Brook stickleback is a species of concern in Pennsylvania (Schmidt, 2006).

\section{Sunfishes (Centrarchidae)}

Several non-native sunfish species, including but not limited to bluegill (Lepomis macrochirus), largemouth bass (Micropterus salmoides), and black crappie (Pomoxis nigromaculatus), have been introduced into reservoirs and gravel pits throughout the plains portion of the St. Vrain River Basin and other parts of Colorado for sport-fishing opportunities. These species never make up a large portion of samples in plains streams in terms of their abundance, nor do they appear to reproduce in these habitats in Colorado. These non-native species have been collected periodically from all segments of the plains portion of St. Vrain Creek (CDOW fish database). The influence of these non-native predators on native fishes is currently unknown.

Green sunfish (Lepomis cyanellus) is commonly found in permanent streams of the plains portion of the South Platte River Basin and in lower portions of South Platte tributaries, but they are never collected in large numbers (Propst, 1982). This species inhabits locations with moderate nutrient enrichment and a variety of physical and chemical conditions; however, Propst (1982) reported it only from sites that had either deep, vegetated potholes or structured banks and large pools. Adult green sunfish consume fish, including younger green sunfish, insects, and crayfish (Schrader, 1989 and citations within). Males build nests and guard their young. Juday (1905) reported the first records of green sunfish from the plains portion of St. Vrain Creek. This species has been and continues to be consistently collected at sites upstream from Highway 287 (segments 1 and 2); however, the occurrence of this species downstream from Highway 287 (segment 3) appears to be sporadic, only being reported on a few occasions (CDOW fish database).

Orangespotted sunfish (Lepomis humilis) is considered rare in the South Platte River Basin (Nesler and others, 1997) and has been collected occasionally from sites in the plains portion of St. Vrain Creek. This species prefers habitat similar to green sunfish, such as deep, slow-velocity pools with cover (Propst, 1982). Propst further reports the association of this species with pools containing root systems of large cottonwoods. Their primary food includes insects and crustaceans with occasional occurrences of fish scales, algae, and small fish (Schrader, 1989 and citations within). Males build nests and guard their young. Juday (1905) first reported orangespotted sunfish from a site presumably near Highway 287 (segment 2) in St. Vrain Creek. This species has also been collected above Hover Road in segment 1 (CDOW fish database).

\section{Perches (Percidae)}

Iowa darter (Etheostoma exile) exists in low numbers in the South Platte River Basin even though populations are considered stable in Colorado (Nesler and others, 1997). It inhabits cool clear streams with sand substrates and is found in cool off-channel environments with rooted vegetation (Woodling, 1985; Nesler and others, 1997). Propst (1982) found Iowa darter associated with undercut stream banks with vegetative cover. Diet mostly consists of amphipods, copepods, and aquatic insects (Schrader, 1989 and citations within). Little is known about the life history of Iowa darter in Colorado. Iowa darter is occasionally collected from St. Vrain Creek at sites just upstream from the WWTP (CDOW fish database). This species is listed as a species of special concern in Colorado because of its apparent specialized habitat requirements that occurs in areas of Colorado that are under rapid urban development (Nesler and others, 1997). Iowa darter also is a species of concern in Ohio and Vermont and is endangered in Illinois (Nesler and others, 1997; Schmidt, 2006).

Johnny darter (Etheostoma nigrum) inhabits foothill streams of the South Platte River Basin, where it was once considered common by early workers (Jordon, 1891; Juday, 1905; Ellis, 1914). Since that time its abundance and distribution have generally declined (Propst and Carlson, 1989). The Johnny darter prefers shallow, slow-to-moderate velocity runs with cobble bottoms and shallow backwater. Propst (1982) reported this species to be absent from silt-laden-stream reaches below irrigation return flows and noticed the absence of Johnny darter when large numbers of crayfish were present. In Colorado, diet consists largely of midge larvae, and eggs are deposited on the undersides of smooth, elevated cobble (Propst and Carlson, 1989). Johnny darter has been consistently collected in low numbers from St. Vrain Creek above and below the WWTP (CDOW fish database). A better understanding of the current distribution and abundance of Johnny darter in St. Vrain Creek would allow comparison with collections made by Propst and Carlson (1989) to help better understand population dynamics of this species.

Non-native yellow perch (Perca flavescens) are introduced into abandoned gravel pits and reservoirs in the plains portion of St. Vrain Creek for recreational opportunities. They have been occasionally collected in St. Vrain Creek at locations near reservoirs where they have been stocked (segments 1 and 3). The influence of yellow perch on native plains fish communities is unknown.

\section{Macroinvertebrate Communities}

Very few collections were made of aquatic invertebrates in the plains portion of the South Platte River Basin prior to the advent of the Clean Water Act in the early 1970s. As a result, very little is known about the aquatic invertebrate 
fauna that historically occurred in St. Vrain Creek or any other plains streams in Colorado. There are sporadic early records of macroinvertebrates from other plains streams where several species have not been recollected (Edmunds and McCafferty, 1984; McCafferty and others, 1993; Kondratieff and Baumann, 2002). Needham and Claassen (1925) first reported the stonefly Isoperla bilineata, a species commonly found in Eastern and Midwestern states, in Colorado, but did not give locality information. Needham and Claassen deposited much of their material in the Entomological Collection at Cornell University, Ithaca, N.Y; however, these specimens could not be located during a recent study (Zuellig and others, 2006). Other stonefly species historically known from transition-zone streams but that have not been recollected include Isogenoides elongatus and Taenionema pacificum (Kondratieff and Baumann, 2002), which were collected in the late 1800s. Other stonefly records collected in the 1940s from the South Platte River at Littleton include the stoneflies Capnia decepta and Capnia vernalis (Illinois Natural History Survey, catalogue numbers, 12103 and 1376), which also have not been recollected at these localities. Additionally, there are early records (late 1800 s early 1900s) of the mayflies McDunnough persimplex and Ephemera compar from transition zone streams that have never been recollected since that time (McCafferty and others, 1993). Ephemera compar is considered an extinct mayfly, as it was only known from the early collection from "Denver Foothills" (McCafferty, 2001). Furthermore, Herrmann and others (1986) reviewed the caddisflies of Colorado and reported on several species from early collections where locality information was vague. They considered these records unreliable because the original specimens could not be verified or additional material was never recollected despite extensive effort.

There is at least partial evidence of changes in macroinvertebrate species distributions in St. Vrain Creek based on the historic record. The earliest records presumed to be from St. Vrain Creek were collected in 1938, well after many modifications had already occurred to Front Range streams. One adult stonefly specimen of Perlesta decipiens, a common Midwestern species, resides in the INHS collection. Locality information associated with this single specimen is "Longmont." Although the specific locality is unknown, it was most likely collected from St. Vrain Creek somewhere near the present day Highway 287, just upstream from the WWTP (segment 2). This species appears to be common in the eastern portion of the South Platte River Basin and is occasionally collected near the plains mountain interface (Zuellig and others, 2006). Although this species is collected from other plains South Platte River Basin localities, it has not been collected from St. Vrain Creek since 1938. It is unknown if this species has been extirpated from St. Vrain Creek.

There are a few more recent examples of macroinvertebrate community change in St. Vrain Creek. Ward (1986) published an extensive study describing macroinvertebrate altitudinal zonation patterns in St. Vrain Creek, but unfortunately sampled only one site on the plains, located approximately 6 miles downstream from the town of Lyons (probably near
Hygiene Road). In this study, Ward reported several species of mayflies (Diphetor hageni, Pseudocloeon dardanum, Epeorus albertae, Nixie spp., Heptagenia elegantula, Rhithrogena hageni, Choroterpes inornata, Paraleptophlebia heteronea, Ephemerella dorothea infrequens, Attenella margarita, and Serratella micheneri), stoneflies (Isoperla quinquepunctata, Skwala americana, Claassenia sabulosa, Triznaka signata), and caddisflies (Glossosoma sp., Nectopsyche sp., and Limnephilus sp.) that have not been found during any of the sampling conducted by the City of Longmont from 2000 to 2006. Because most of the City of Longmont macroinvertebrate samples were identified to the family level, it is uncertain which species may have been eliminated, although some information can be inferred. Recent samples collected during this study also did not include any of the above mentioned genera. Further effort is warranted to determine if these observations are real or a result of small differences in site locations.

\section{Biological Data Synopsis}

At least 33 fish species have been collected from St. Vrain Creek in the study reach since the earliest records of Juday. Twenty-five of these 33 species are considered native to the South Platte River Basin; the remaining 8 are non-native. Of the 25 native species, 2 species (hornyhead chub and blacknose shiner) are considered extirpated from Colorado and 8 (northern redbelly dace, suckermouth minnow, lake chub, brassy minnow, common shiner, stonecat, Iowa darter, and orangespotted sunfish) are state listed as threatened, endangered, or species of concern; many are also species of concern in other states. Of the eight state listed species, three (northern redbelly dace, suckermouth minnow, and lake chub) have not been recollected from the study boundaries since their original early accounts. Of the remaining state listed species known from St. Vrain Creek, two (common shiner and stonecat) are frequently encountered and three are occasionally collected (brassy minnow, Iowa darter, and orangespotted sunfish). The remaining 15 native species include several that are commonly collected (sand shiner, red shiner, creek chub, fathead minnow, longnose dace, longnose sucker, white sucker, green sunfish) and others that are occasionally encountered in comparatively lower abundances (channel catfish, black bullhead, brook stickleback, plains killifish, bigmouth shiner, plains topminnow, and Johnny darter). Remarkably, the 10 state listed or extirpated species described above represent more than 40 percent of the total native fish fauna in the South Platte River Basin that are known from a short section of St. Vrain Creek.

Although much less is known about early macroinvertebrate community structure in St. Vrain Creek, there is evidence that macroinvertebrate communities have changed in other Front Range transitional zone streams. Several species of stoneflies, such as Isoperla bilineata, Isogenoides elongatus, Taenionema pacifica, Capnia decepta, Capnia vernalis, and the mayfly McDunnough persimplex have apparently been locally eliminated from other regional streams. Additionally, the mayfly Ephemera compar is considered extinct 
and the stonefly Perlesta decipiens has not been recollected from St. Vrain Creek since 1938. Several species of mayflies, stoneflies, and caddisflies have been reported from a site presumably near Hygiene Road that have not been recorded by the city of Longmont in their samples collected since 2000 at a nearby downstream site.

St. Vrain Creek continues to harbor native fish species of concern that have declined in other parts of the South Platte River Basin. Generally, fish collections in the Colorado Division of Wildlife fish database and the City of Longmont macroinvertebrate samples from St. Vrain Creek have been collected inconsistently in space and time. Macroinvertebrate samples collected prior to 2005 by the City of Longmont were processed at the family level, making it difficult to determine community response to changing water-quality or habitat conditions. As a result, these data cannot be used to assess the influence of recent upgrades in WWTP operations. If biological data are used to assess the effects of future WWTP upgrades or habitat improvements in St. Vrain Creek, then a monitoring program designed to address specific questions will be necessary for a meaningful interpretation. Additionally, more effort is warranted to better understand the differences between macroinvertebrate collections made by Ward (1986) and by the City of Longmont and to better understand fish community dynamics in St. Vrain Creek. Furthermore, investigation is needed to understand if there are unique characteristics of St. Vrain Creek that allow the persistence of many fish species of concern in Colorado.

\section{Wastewater Compounds}

Wastewater samples were collected at the seven sites during the spring of 2005 and 2006. A Lagrangian-sampling design (following the same parcel of water as it moves downstream) was used during each sampling event, and time-oftravel studies were conducted just prior to each sampling event to determine appropriate sampling times.

\section{Travel-Time Estimation}

Tracer studies provide accurate travel-time estimates within a stream reach. Travel-time estimates from tracer studies may be used to predict the time of arrival and passage of a dissolved constituent accidentally released or spilled upstream. These estimates also may be used to characterize movement of constituents that may be released into a stream intentionally, as in the case of WWTP discharge. In this study, rhodamine-WT dye was used as a tracer. Rhodamine-WT dye acts as a solute and completely mixes with the stream, simulating movement and dispersion of water particles (Ruddy and Britton, 1989). Rhodamine-WT has a highly detectable fluorescence that is easily isolated from background fluorescence and is harmless at the low concentrations used in this study. Fluorometry is a widely accepted technique for tracer measurements, as it provides simple and accurate stream-tracer detection at low concentrations of rhodamine-WT dye (Wilson and others, 1986).

\section{Rhodamine-WT Injection and Sampling}

Travel times in the study reach were estimated twice, once in April of 2005 and again in March of 2006. Sluginjection dye doses were prepared by mixing a predetermined amount of dye into a small volume of water. The mixed dye was poured rapidly into the center of the stream, and a quick rinse of the container removed any remaining dye. The amount of dye used for each injection was determined using the following equation (Kilpatrick, 1970):

$$
V_{d}=3.4 \times 10^{-4}\left(\frac{Q_{m} L}{v}\right)^{0.93} C_{p}
$$

where

$V_{d} \quad$ is the volume of rhodamine-WT dye;

$Q_{m}$ is the mean discharge of the reach, in cubic feet per second;

$L \quad$ is the reach length, in miles;

$v \quad$ is the mean stream velocity, in feet per second; and

$C_{p} \quad$ is the peak concentrations desired at the end of the reach, in micrograms per liter.

Mean velocities and discharges throughout the reach were measured several days prior to the tracer experiment.

Grab samples were collected from the center of the stream at each site. A part of each sample was measured onsite to determine the arrival of the leading edge, peak, and trailing edge of the dye plume. Samples were collected approximately every 15 minutes prior to the arrival of the leading edge and then every 5 minutes until 10 percent of the peak concentration was reached. Because fluorescence is temperature dependent, the remainder of each sample was measured again at a constant temperature in the USGS Colorado Water Science Center Laboratory in Lakewood. All dye measurements were made using either a Turner Model 10 bench fluorometer or a Turner Design-360 portable fluorometer. Travel times were defined as the elapsed time for the dye peak to travel between two monitoring sites.

In order to complete the tracer studies over the full study reach in a reasonable amount of time, the stream was divided into segments where individual injections occurred (two segments in 2005 and three segments in 2006). On April 5, 2005, the first injection site was at the intersection of Airport Road and St. Vrain Creek, where 80 milliliters of dye were injected. The movement of this dye was monitored at three downstream sites-M9, the intersection of Boston Avenue and St. Vrain Creek, and M8 (table 2). The second injection site was immediately upstream from the bridge at the intersection of South Pratt Parkway and St. Vrain Creek, where 200 milliliters of dye were injected. The movement of this dye was monitored at four downstream sites-M8, M6, the intersection of Weld County Road 1 and St. Vrain Creek, and M4 (table 2). 
Table 2. Travel-time results for the April 5, 2005, tracer study, St. Vrain Creek.

[E, estimated]

\begin{tabular}{|c|c|c|c|c|c|c|}
\hline \multirow{2}{*}{ Collection site } & \multirow{2}{*}{$\begin{array}{c}\text { Distance } \\
\text { from first } \\
\text { injection } \\
\text { point } \\
\text { (miles) }\end{array}$} & \multicolumn{3}{|c|}{$\begin{array}{l}\text { Cumulative travel time of dye cloud } \\
\text { (minutes) }\end{array}$} & \multirow{2}{*}{$\begin{array}{l}\text { Average velocity } \\
\text { of peak between } \\
\text { adjacent sites } \\
\text { (miles per hour) }\end{array}$} & \multirow{2}{*}{$\begin{array}{c}\text { Discharge at } \\
\text { site } \\
\text { (cubic feet } \\
\text { per second) }\end{array}$} \\
\hline & & Leading edge & Peak & Trailing edge & & \\
\hline M9 & 0.7 & 40 & 90 & 180 & 0.47 & 42.0 \\
\hline Boston Avenue and St. Vrain Creek & 2.45 & 200 & 250 & 410 & .66 & 40.2 \\
\hline M8 & 4.19 & 355 & 435 & 625 & .56 & 42.1 \\
\hline M6 & 4.98 & 435 & 500 & 540 & .73 & 76.0 \\
\hline $\begin{array}{l}\text { Weld County Road } 1 \text { and St. Vrain } \\
\text { Creek }\end{array}$ & 6.07 & 500 & 585 & 670 & .77 & E78.0 \\
\hline M4 & 9.37 & 630 & 735 & 940 & 1.32 & 140 \\
\hline
\end{tabular}

On March 14, 2006, the first injection site was at the intersection of Airport Road and St. Vrain Creek, where 80 milliliters of dye were injected. The movement of this dye was monitored at three downstream sites-M9, the intersection of Boston Avenue and St. Vrain Creek, and the intersection of South Pratt Parkway and St. Vrain Creek (table 3). The second injection site was at the intersection of Boston Avenue and St. Vrain Creek, where 110 milliliters of dye were injected. The movement of this dye was monitored at three downstream sites-the intersection of South Pratt Parkway and St. Vrain Creek, M8, and M6 (table 3). The third injection site was immediately upstream from the bridge at the intersection of North 119th Street and St. Vrain Creek, where 200 milliliters of dye were injected. The movement of this dye was monitored at three downstream sites-M6, the intersection of Weld County Road 1 and St. Vrain Creek, and M4 (table 3).

A rating curve of the logarithm of the travel-time estimates and the logarithm of the stream discharge measurements was developed to estimate travel times in the study reach at the slightly different stream discharges encountered during the subsequent synoptic sampling in 2005 and 2006. For the synoptic sampling in 2005, streamflow had increased slightly compared to the tracer study only between sites M6 and M4, and the travel time between these two sites was adjusted. For the synoptic sampling in 2006, streamflow had decreased slightly compared to the tracer study only between sites M9 and M8, and the travel time between these two sites was adjusted.

\section{Lagrangian Synoptic}

Wastewater samples were collected using standardized depth- and width-integrating techniques and were processed and preserved onsite using standard methods described in
U.S. Geological Survey (variously dated). Samples were analyzed at the USGS National Water Quality Laboratory in Denver, Colo., according to methods described in Zaugg and others (2002). Quality-control samples, including one field blank, one replicate, and one laboratory spike, were collected during each sampling event. In addition, field measurements were obtained for water temperature, dissolved oxygen, $\mathrm{pH}$, specific conductance, and discharge at the time of sampling.

Samples were collected longitudinally in a Lagrangian manner at specific times calculated from the travel-time data. Lagrangian sampling follows the same parcel of water as it moves downstream. Sampling times were based on the stream velocity between sites; sampling occurred when it was estimated that the target parcel of water had reached each site. Sampling in this manner allows changes in chemical concentration due to instream processing, attenuation, and dilution to be isolated from changes in upstream loading over time. Results from the Lagrangian synoptic are presented in table 4 .

\section{Hydrophobic Organic Compounds}

Six-inch SPMDs were deployed at six sites (not including O1) in spring of 2005 and 2006, for approximately 4 weeks. To prevent the rhodamine-WT dye from interfering with the target chemicals, the SPMDs were deployed at least a week before or after the travel-time experiments. After retrieval, contaminant residues concentrated in the SPMDs were recovered and separated from the lipid by dialysis in iso-octane at Environmental Sampling Technologies, in St. Joseph, Mo., by using methods described in Huckins and others (1990). The U.S. Army Corp of Engineers Environmental Laboratory in Vicksburg, Miss., then used the dialysate in toxicity testing. This toxicity assay, the P450RGS test, provides a rapid screen for aryl hydrocarbon receptor (AhR) type compounds that include PCBs, PAHs, dioxins, and furans 
Table 3. Travel-time results for the March 14, 2006, tracer study, St. Vrain Creek.

[E, estimated]

\begin{tabular}{|c|c|c|c|c|c|c|}
\hline \multirow{2}{*}{ Collection site } & \multirow{2}{*}{$\begin{array}{c}\text { Distance } \\
\text { from first } \\
\text { injection } \\
\text { point } \\
\text { (miles) }\end{array}$} & \multicolumn{3}{|c|}{$\begin{array}{l}\text { Cumulative travel time of dye cloud } \\
\text { (minutes) }\end{array}$} & \multirow{2}{*}{$\begin{array}{l}\text { Average velocity } \\
\text { of peak between } \\
\text { adjacent sites } \\
\text { (miles per hour) }\end{array}$} & \multirow{2}{*}{$\begin{array}{c}\text { Discharge at } \\
\text { site } \\
\text { (cubic feet } \\
\text { per second) }\end{array}$} \\
\hline & & Leading edge & Peak & Trailing edge & & \\
\hline M9 & 0.7 & 100 & 180 & 310 & 0.23 & 10.3 \\
\hline Boston Avenue and St. Vrain Creek & 2.45 & 400 & 550 & 780 & .28 & 11.8 \\
\hline $\begin{array}{l}\text { South Pratt Parkway and St. Vrain } \\
\text { Creek }\end{array}$ & 3.1 & 550 & 780 & 1,090 & .17 & 15.2 \\
\hline M8 & 4.19 & 910 & 1,005 & 1,150 & .29 & 15.9 \\
\hline M6 & 4.98 & 950 & 1,050 & 1,250 & 1.05 & E33.0 \\
\hline $\begin{array}{l}\text { Weld County Road } 1 \text { and St. Vrain } \\
\text { Creek }\end{array}$ & 6.07 & 1,040 & 1,170 & 1,350 & .55 & 34.0 \\
\hline M4 & 9.37 & 1,280 & 1,340 & 1,520 & 1.16 & E90.0 \\
\hline
\end{tabular}

(Murk and others, 1996). All vertebrates produce detoxifying enzymes upon exposure to AhR compounds; the amount of enzymes produced is directly proportional to the concentration of the compounds. Quantifying one of these enzymes (the gene CYP1A1) serves as a measure of dioxin activity. The concentration of AhR compounds in the SPMD extract that induce CYP1A1 production will be expressed as the amount of dioxin, in toxic equivalents (TEQs), that would induce the same response.

Quality-control samples for the SPMDs, including two replicates, one dialysis blank, and one trip blank, were collected during each sampling period. During processing in the laboratory, dialysis blanks were collected to monitor for possible manufacturing and laboratory contamination. Trip blanks were collected in the field by exposing an SPMD to the air for the amount of time it took to remove an SPMD from the canister and place it in the stream, and then to remove the same SPMD from the stream and place it back into the canister. With the trip blank, however, the SPMD was left in the canister whereas the field-SPMDs were deployed in the stream. In this way, the trip blank mimicked exposure to airborne chemical contamination that field-deployed SPMDs experienced during deployment and retrieval.

In 2005, the only compound detected in the blank sample was phenol; in 2006, both methyl salicylate and naphthalene were detected in the blank sample (table 4). In many cases, the concentration in the blank sample was greater than the respective concentrations in the environmental samples. Concentrations in blank samples can be used to assess potential contamination made during field collection and (or) laboratory analysis. In 2005, the percent difference in the concentrations of the replicate samples ranged from 0 to 58 ; the maximum percent difference was in beta-stigmastanol (table 5). In 2006, the percent difference in the concentrations of the replicate samples ranged from 0 to 100 (with the 100 percent difference indicating that one value out of the replicate pair was censored and the other was not); the maximum percent difference was in naphthalene (table 5). These percent difference values can be used to characterize potential variability in reported concentrations of each compound. Spike recoveries in 2005 and 2006 are shown in table 5. In 2005, percent recoveries of the spiked concentrations ranged from 40 to 172 , with a mean of 89 ; in 2006, percent recoveries ranged from 23 to 206, with a mean of 101 . Percent recovery of spike concentrations can be used to characterize potential recovery of these compounds during field collection and laboratory analysis.

In 2005, one laboratory replicate out of three had a detection in the toxicity assay of the dialysis blank, indicating potential for low-level contamination from manufacturing or laboratory processing during dialysis (table 6). The value in the trip blank was slightly higher than in the dialysis blank, indicating that there may have been additional low-level atmospheric contamination. In 2006, there were no detections in the toxicity assay of the dialysis or trip blank. In 2005, the percent difference in the values of the replicate samples ranged from 5 to 35 ; in 2006, they ranged from 1 to 13 (table 6).

\section{Acknowledgments}

The authors gratefully acknowledge all those who helped with field work, including Norm Spahr, Alan Duran, Bret Bruce, Jason Gurdak, Jeff Bails, and Carmia Fiechtner from the USGS and Mary Paterniti and Kathryn Marko from the City of Longmont. Additionally, comments provided by Harry Crockett and Nicole Vieira with the Colorado Division of Wildlife and Bill Battaglin and Bret Bruce with the USGS greatly improved the quality of this data series report. 


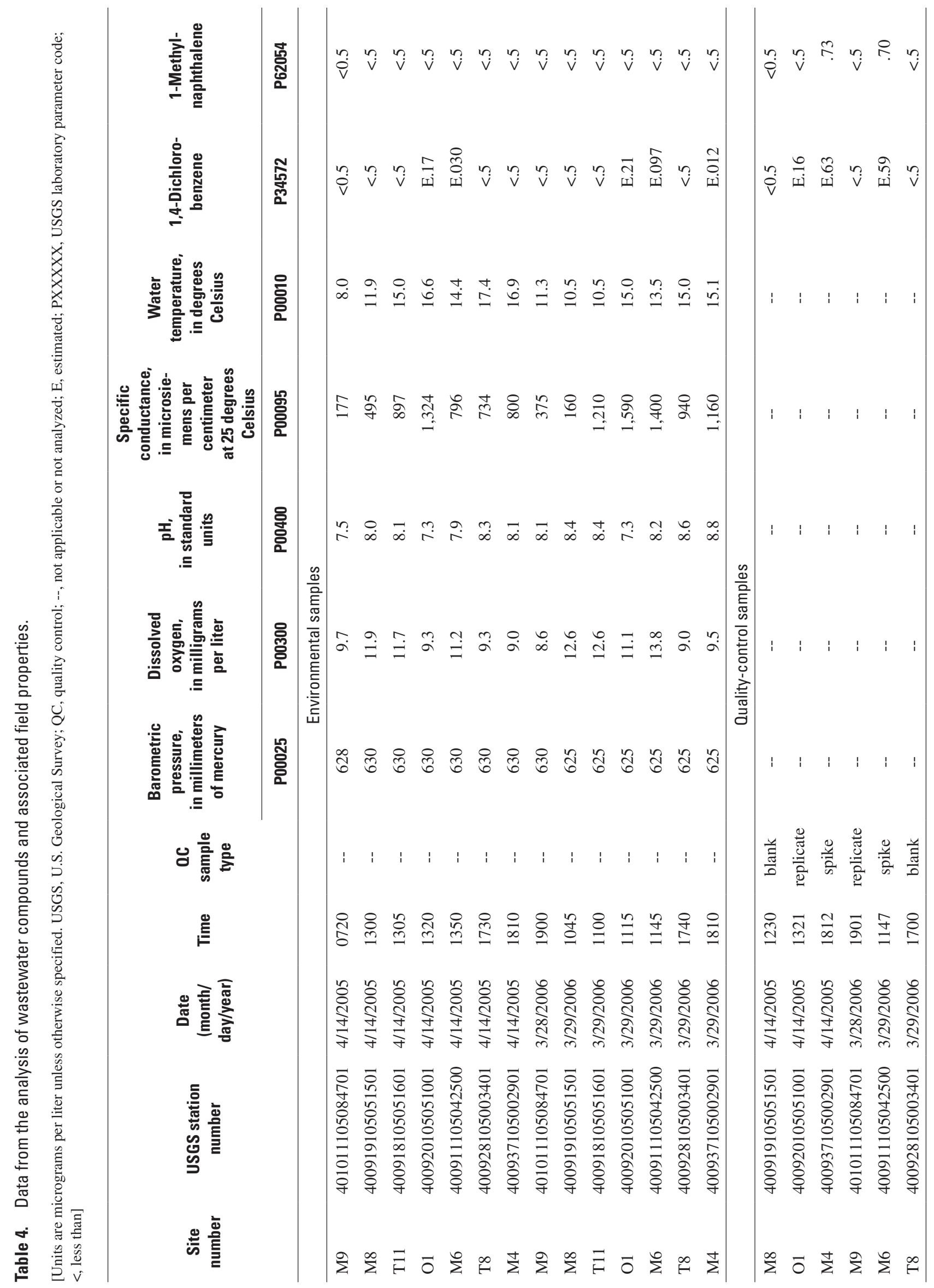




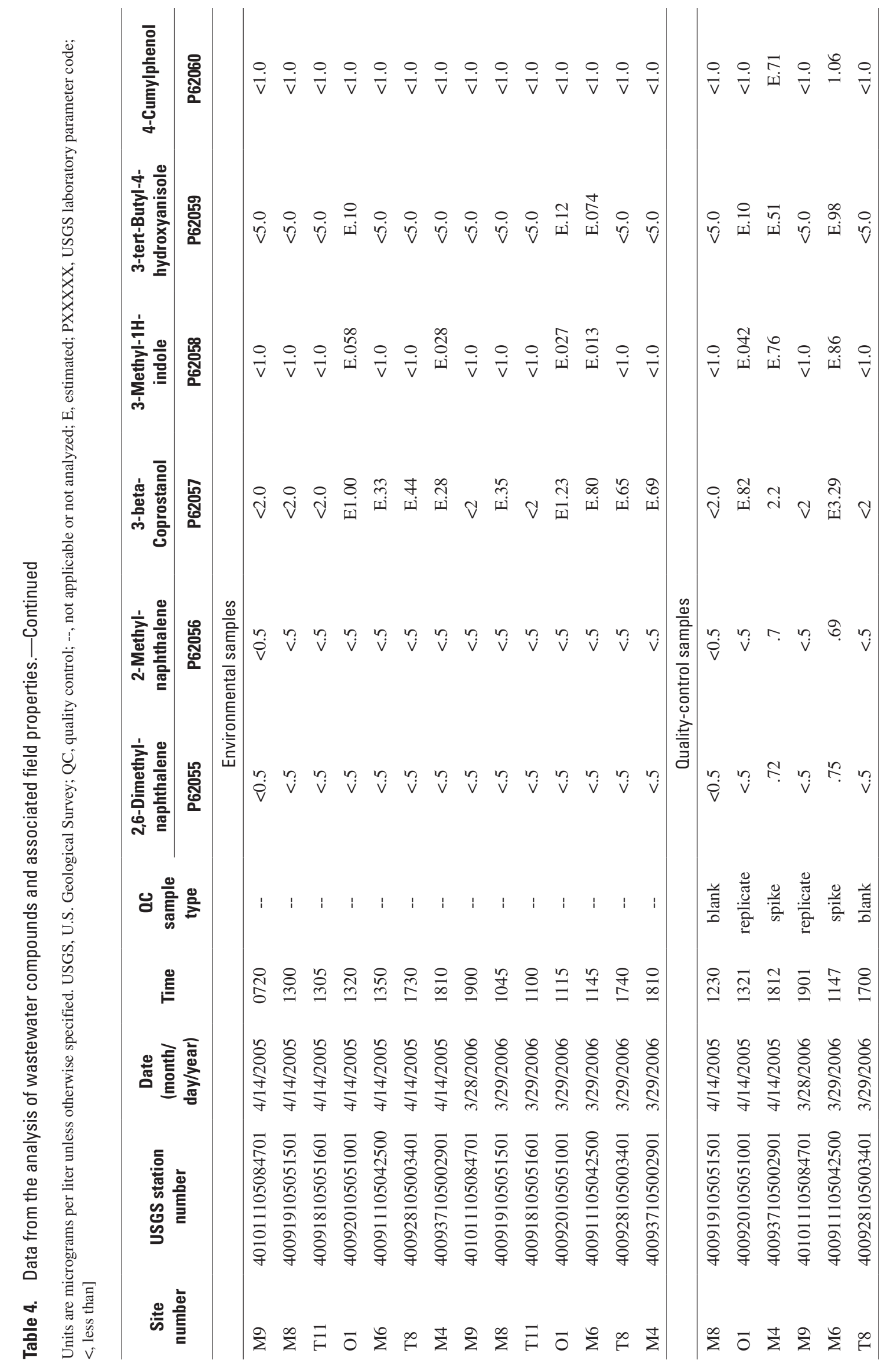




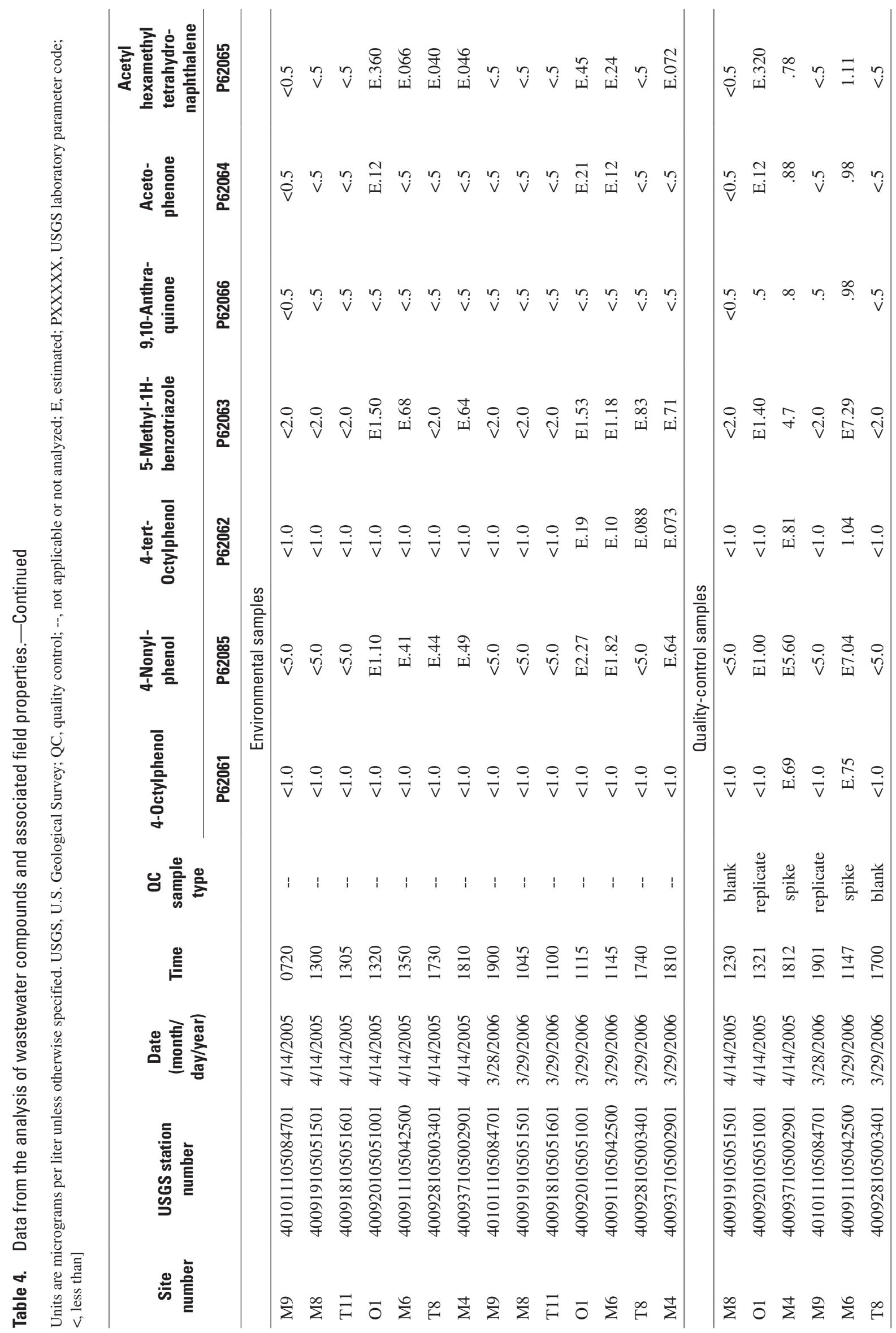




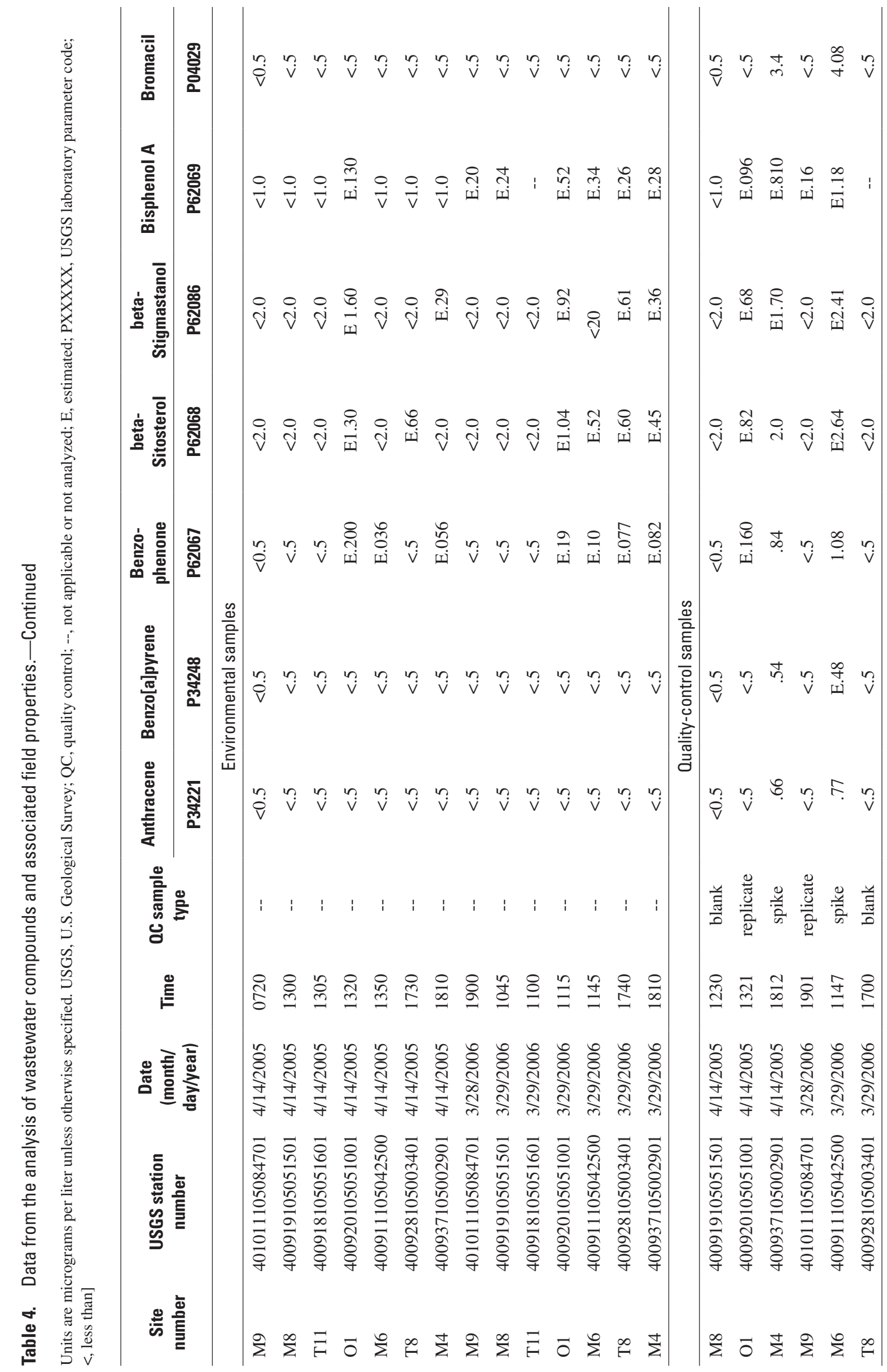




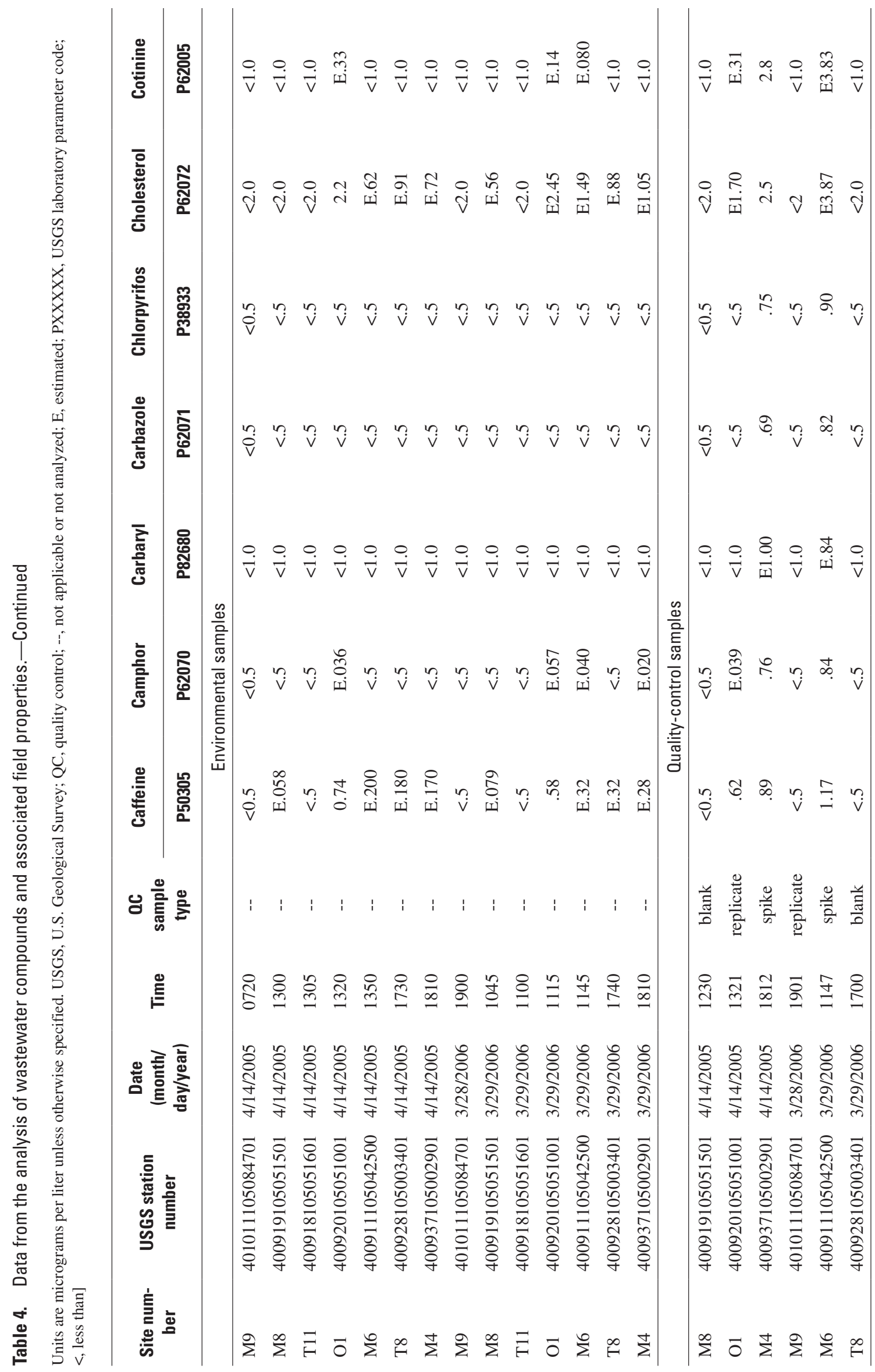




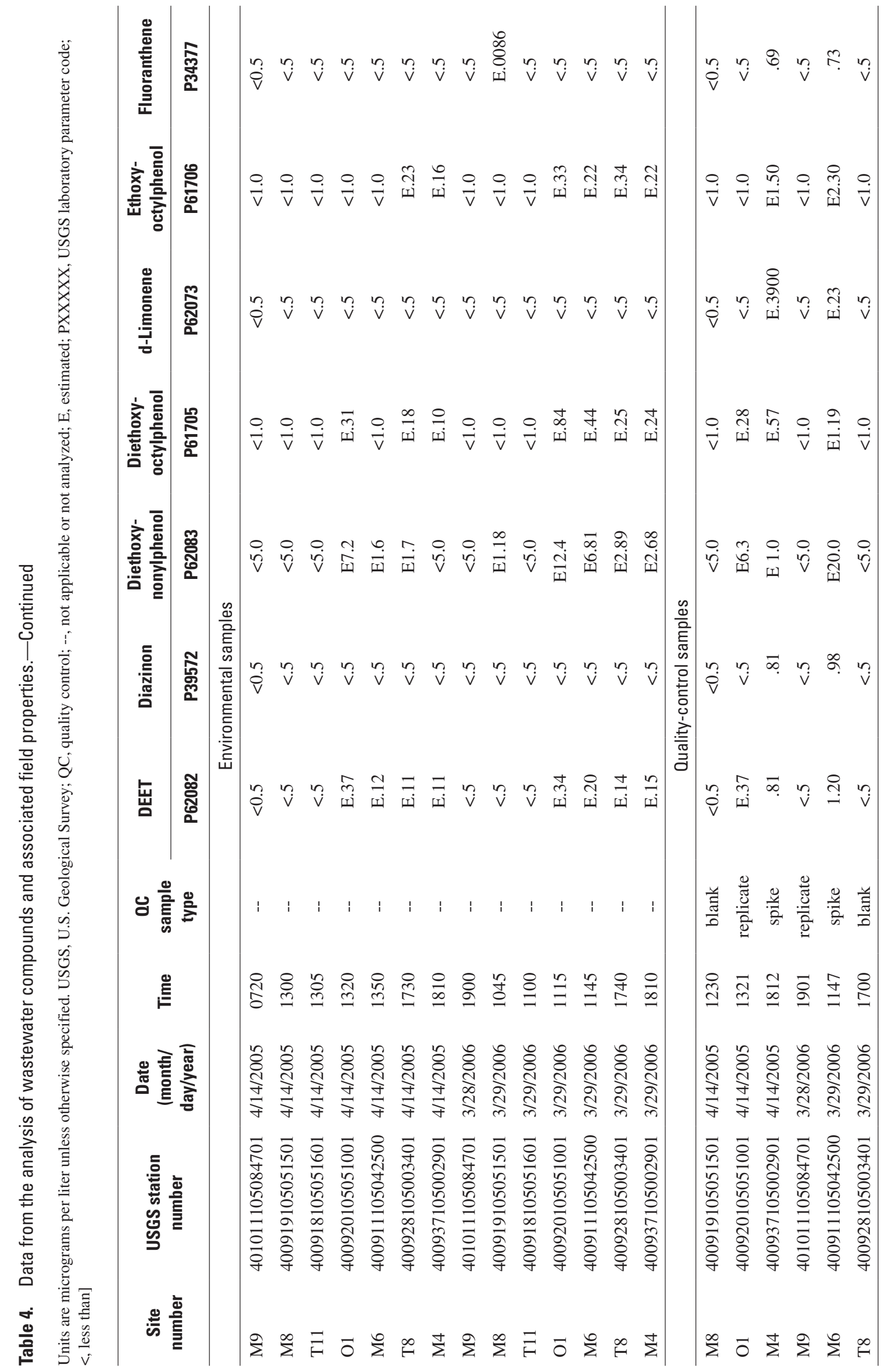




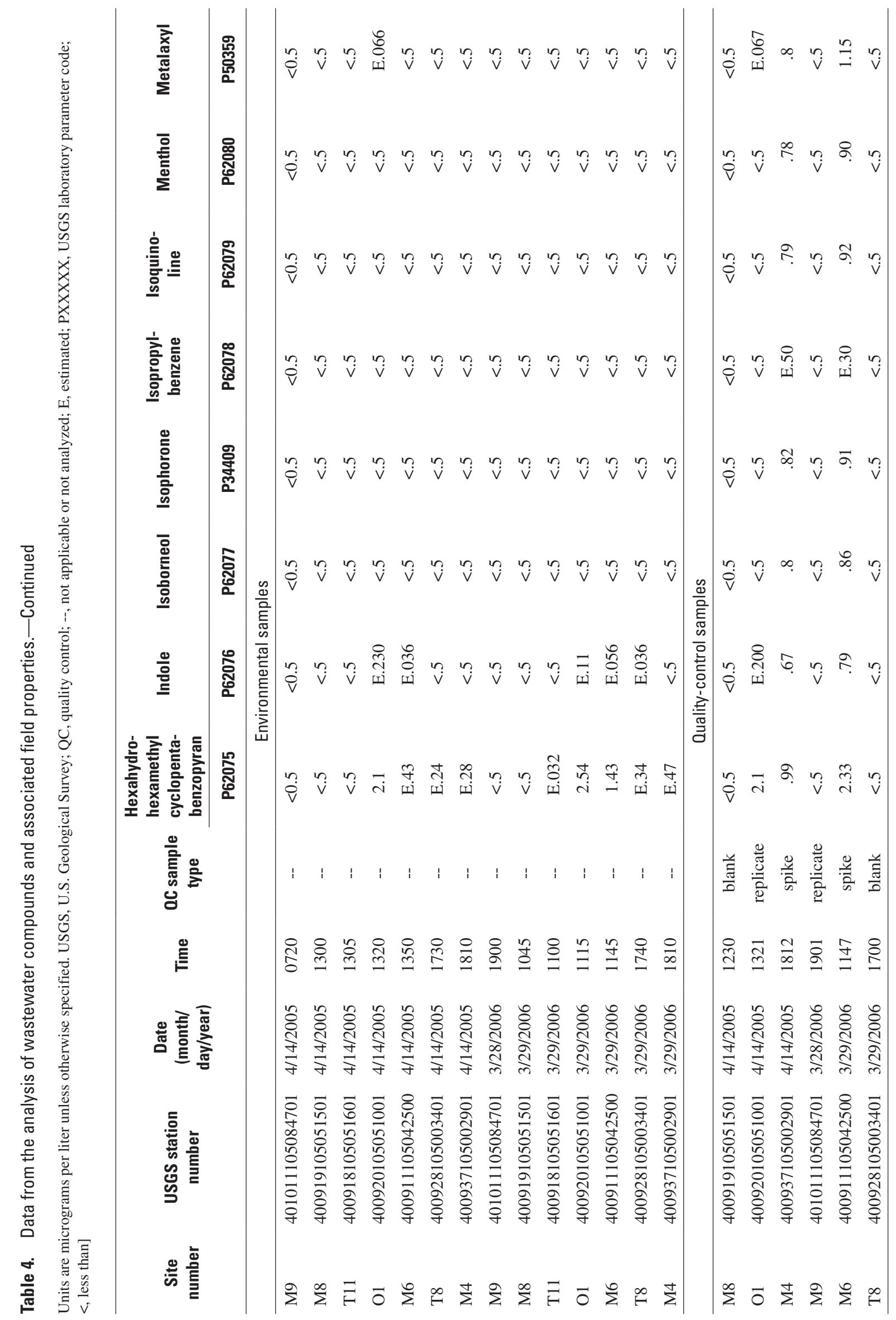




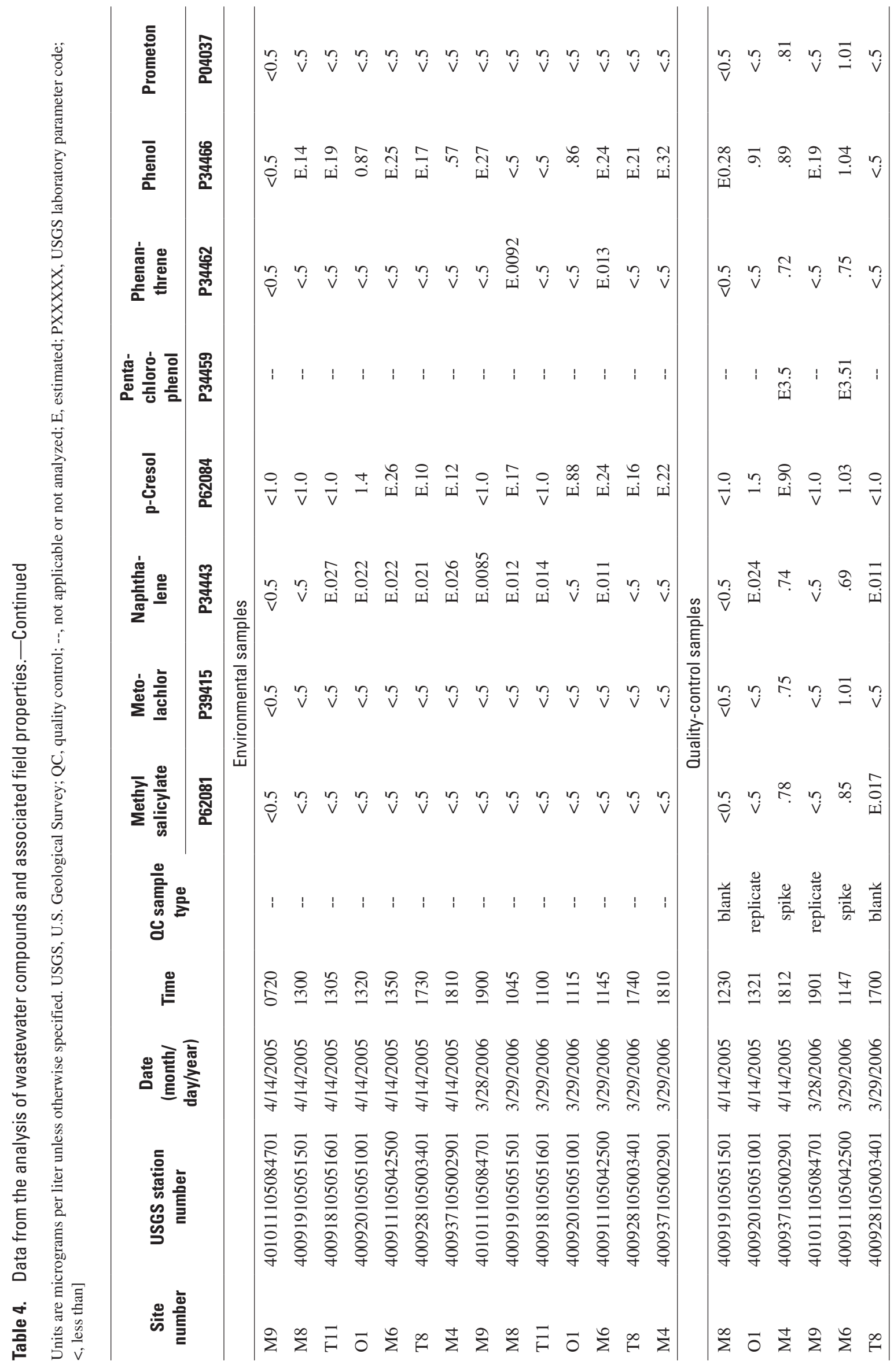




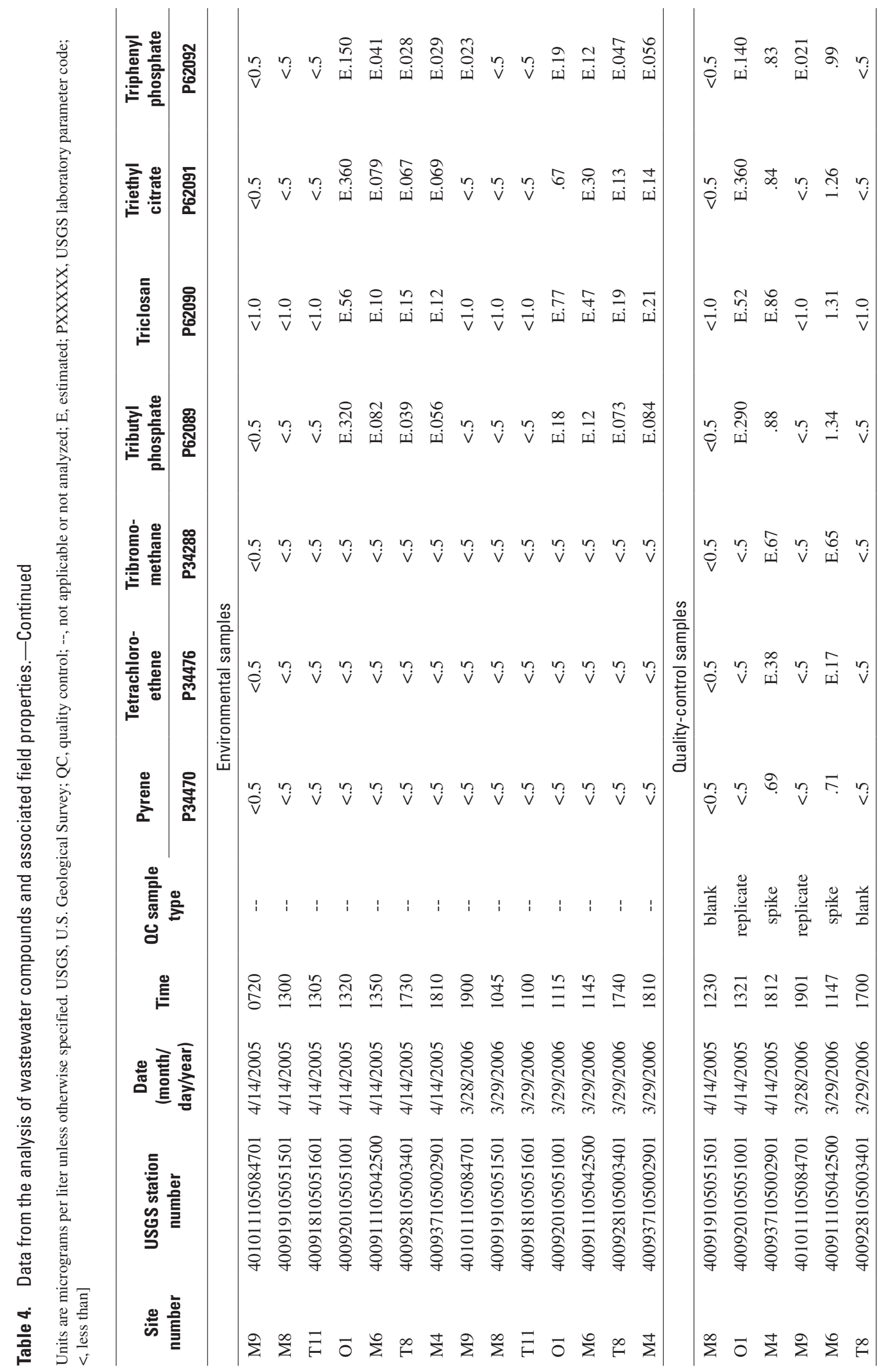




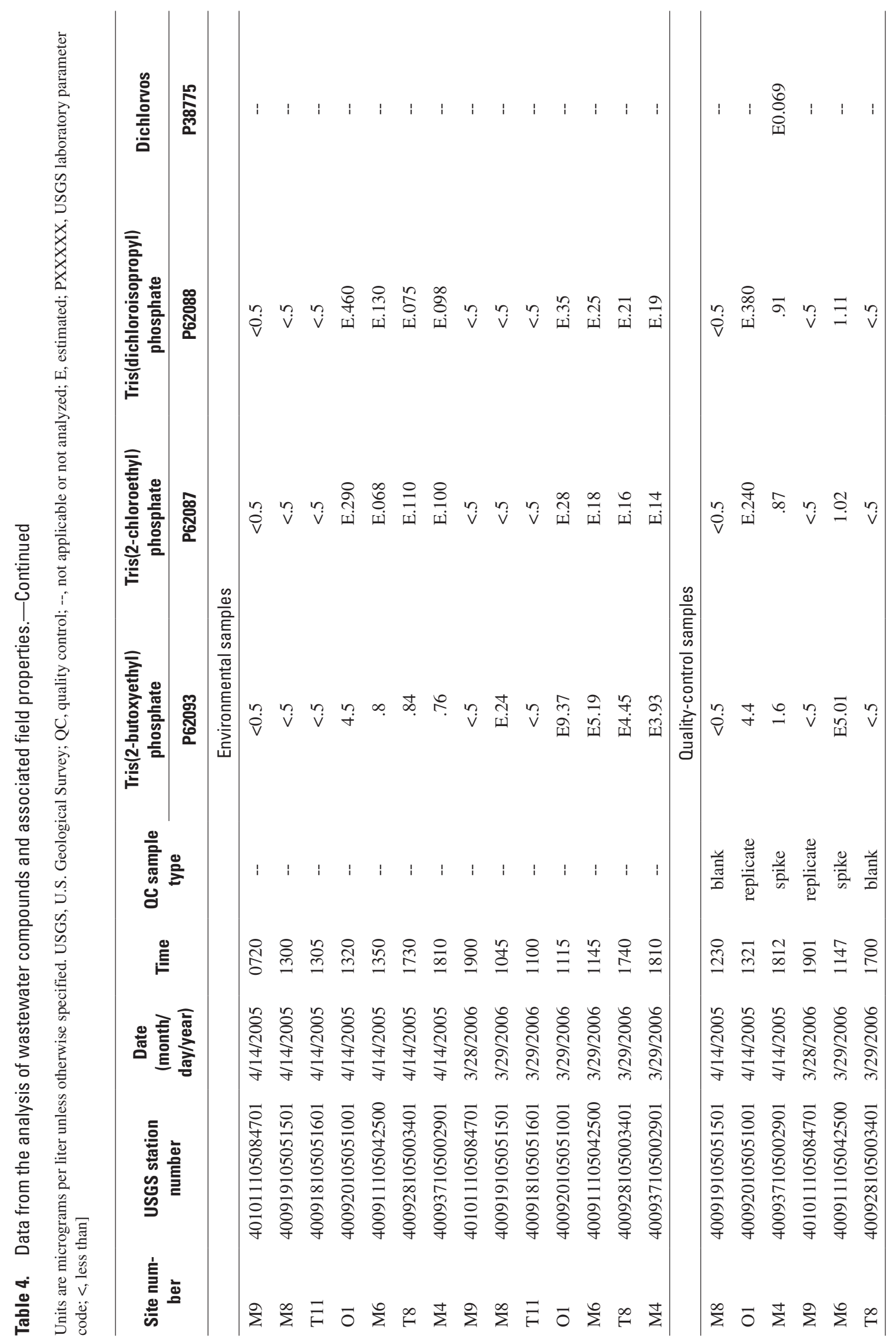


Table 5. Percent difference between environmental and replicate samples and percent recovery of spike concentrations of wastewater compounds.

\begin{tabular}{|c|c|c|c|c|c|}
\hline \multirow{2}{*}{$\begin{array}{l}\text { U.S. Geological } \\
\text { Survey param- } \\
\text { eter code }\end{array}$} & \multirow[t]{2}{*}{ Parameter name } & \multicolumn{2}{|c|}{$\begin{array}{c}\text { Percent difference between } \\
\text { environmental and replicate } \\
\text { samples }\end{array}$} & \multicolumn{2}{|c|}{$\begin{array}{l}\text { Percent recovery of spike } \\
\text { concentrations }\end{array}$} \\
\hline & & 2005 & 2006 & 2005 & 2006 \\
\hline 34572 & 1,4-Dichlorobenzene & 6 & 0 & 79 & 61 \\
\hline 62054 & 1-Methylnaphthalene & 0 & 0 & 91 & 88 \\
\hline 62055 & 2,6-Dimethylnaphthalene & 0 & 0 & 90 & 93 \\
\hline 62056 & 2-Methylnaphthalene & 0 & 0 & 88 & 86 \\
\hline 62057 & 3-beta-Coprostanol & 18 & 0 & 60 & 78 \\
\hline 62058 & 3-Methyl-1H-indole & 28 & 0 & 92 & 106 \\
\hline 62059 & 3-tert-Butyl-4-hydroxyanisole & 0 & 0 & 64 & 113 \\
\hline 62060 & 4-Cumylphenol & 0 & 0 & 89 & 133 \\
\hline 62061 & 4-Octylphenol & 0 & 0 & 86 & 94 \\
\hline 62085 & 4-Nonylphenol & 9 & 0 & 80 & 82 \\
\hline 62062 & 4-tert-Octylphenol & 0 & 0 & 101 & 117 \\
\hline 62063 & 5-Methyl-1H-benzotriazole & 7 & 0 & 63 & 95 \\
\hline 62066 & Anthraquinone & 0 & 0 & 100 & 123 \\
\hline 62064 & Acetophenone & 0 & 0 & 110 & 108 \\
\hline 62065 & Acetyl-hexamethyl-tetrahydro-naphthalene & 11 & 0 & 92 & 108 \\
\hline 34221 & Anthracene & 0 & 0 & 83 & 96 \\
\hline 34248 & Benzo[a]pyrene & 0 & 0 & 68 & 60 \\
\hline 62067 & Benzophenone & 20 & 0 & 98 & 122 \\
\hline 62068 & beta-Sitosterol & 37 & 0 & 63 & 66 \\
\hline 62086 & beta-Stigmastanol & 58 & 0 & 44 & 75 \\
\hline 62069 & Bisphenol A & 26 & 16 & 101 & 106 \\
\hline 04029 & Bromacil & 0 & 0 & 106 & 128 \\
\hline 50305 & Caffeine & 16 & 0 & 90 & 106 \\
\hline 62070 & Camphor & 8 & 0 & 95 & 100 \\
\hline 82680 & Carbaryl & 0 & 0 & 125 & 105 \\
\hline 62071 & Carbazole & 0 & 0 & 86 & 102 \\
\hline 38933 & Chlorpyrifos & 0 & 0 & 94 & 113 \\
\hline 62072 & Cholesterol & 23 & 0 & 56 & 74 \\
\hline 62005 & Cotinine & 6 & 0 & 88 & 117 \\
\hline 62082 & N,N-diethyl-meta-toluamide (DEET) & 0 & 0 & 88 & 125 \\
\hline 39572 & Diazinon & 0 & 0 & 101 & 123 \\
\hline 62083 & Diethoxynonylphenol & 13 & 0 & 172 & 206 \\
\hline 61705 & Diethoxyoctylphenol & 10 & 0 & 100 & 159 \\
\hline 62073 & d-Limonene & 0 & 0 & 49 & 29 \\
\hline 61706 & Monoethoxyoctylphenol & 0 & 0 & 84 & 130 \\
\hline 34377 & Fluoranthene & 0 & 0 & 86 & 91 \\
\hline 62075 & Hexahydrohexamethyl cyclopentabenzopyran & 0 & 0 & 89 & 113 \\
\hline 62076 & Indole & 13 & 0 & 84 & 92 \\
\hline
\end{tabular}


Table 5. Percent difference between environmental and replicate samples and percent recovery of spike concentrations of wastewater compounds.-Continued

\begin{tabular}{|c|c|c|c|c|c|}
\hline \multirow{2}{*}{$\begin{array}{l}\text { U.S. Geological } \\
\text { Survey param- } \\
\text { eter code }\end{array}$} & \multirow[t]{2}{*}{ Parameter name } & \multicolumn{2}{|c|}{$\begin{array}{l}\text { Percent difference between } \\
\text { environmental and replicate } \\
\text { samples }\end{array}$} & \multicolumn{2}{|c|}{$\begin{array}{l}\text { Percent recovery of spike } \\
\text { concentrations }\end{array}$} \\
\hline & & 2005 & 2006 & 2005 & 2006 \\
\hline 62077 & Isoborneol & 0 & 0 & 100 & 108 \\
\hline 34409 & Isophorone & 0 & 0 & 103 & 114 \\
\hline 62078 & Isopropylbenzene & 0 & 0 & 63 & 38 \\
\hline 62079 & Isoquinoline & 0 & 0 & 99 & 115 \\
\hline 62080 & Menthol & 0 & 0 & 98 & 112 \\
\hline 50359 & Metalaxyl & 2 & 0 & 100 & 144 \\
\hline 62081 & Methyl salicylate & 0 & 0 & 98 & 106 \\
\hline 39415 & Metolachlor & 0 & 0 & 94 & 126 \\
\hline 34443 & Naphthalene & 9 & 100 & 89 & 85 \\
\hline 62084 & p-Cresol & 7 & 0 & 98 & 99 \\
\hline 34462 & Phenanthrene & 0 & 0 & 90 & 92 \\
\hline 34466 & Phenol & 5 & 30 & 40 & 100 \\
\hline 04037 & Prometon & 0 & 0 & 101 & 126 \\
\hline 34470 & Pyrene & 0 & 0 & 86 & 89 \\
\hline 34476 & Tetrachloroethylene & 0 & 0 & 48 & 22 \\
\hline 34288 & Bromoform & 0 & 0 & 84 & 82 \\
\hline 62089 & Tributyl phosphate & 9 & 0 & 103 & 152 \\
\hline 62090 & Triclosan & 7 & 0 & 93 & 105 \\
\hline 62091 & Triethyl citrate & 0 & 0 & 96 & 120 \\
\hline 62092 & Triphenyl phosphate & 7 & 6 & 100 & 109 \\
\hline 62093 & Tris(2-butoxyethyl) phosphate & 2 & 0 & 105 & -23 \\
\hline 62087 & Tris(2-chloroethyl) phosphate & 17 & 0 & 96 & 105 \\
\hline 62088 & Tris(dichloroisopropyl) phosphate & 17 & 0 & 102 & 108 \\
\hline
\end{tabular}


Table 6. Data from the toxicity assays conducted on dialysates from the semipermeable membrane devices.

[USGS, U.S. Geological Survey; LR, laboratory replicate; --, not applicable; <, less than; \%difference, percent difference between the environmental and replicate samples]

\begin{tabular}{|c|c|c|c|c|c|c|c|c|}
\hline \multirow{3}{*}{$\begin{array}{c}\text { Site } \\
\text { number }\end{array}$} & \multirow{3}{*}{$\begin{array}{l}\text { USGS station } \\
\text { number }\end{array}$} & \multirow{3}{*}{$\begin{array}{c}\text { Type of } \\
\text { quality-control } \\
\text { sample }\end{array}$} & \multicolumn{6}{|c|}{ Toxicity, in picograms of toxic equivalents per milliliter } \\
\hline & & & \multicolumn{3}{|c|}{2005 sampling event } & \multicolumn{3}{|c|}{2006 sampling event } \\
\hline & & & LR 1 & LR 2 & LR 3 & LR 1 & LR 2 & LR 3 \\
\hline \multicolumn{9}{|c|}{ Environmental samples } \\
\hline M9 & 401011105084701 & -- & 132 & 145 & $<125$ & 229 & 179 & 262 \\
\hline M8 & 400919105051501 & -- & 1,993 & 2,460 & 2,215 & 1,227 & 1,127 & 1,145 \\
\hline $\mathrm{T} 11$ & 400918105051601 & -- & 907 & 1,333 & 926 & 458 & 477 & 436 \\
\hline M6 & 400911105042500 & -- & 2,038 & 1,604 & 1,606 & 816 & 673 & 830 \\
\hline $\mathrm{T} 8$ & 400928105003401 & -- & 941 & 950 & 804 & 895 & 822 & 909 \\
\hline M4 & 400937105002901 & -- & 916 & 1,189 & 957 & 937 & 951 & 1,265 \\
\hline \multicolumn{9}{|c|}{ Quality-control samples } \\
\hline M6 & 400911105042500 & Replicate & 1,581 & 1,522 & 1,516 & -- & -- & -- \\
\hline M6 & 400911105042500 & $\%$ difference & 29 & 5 & 6 & -- & -- & -- \\
\hline M4 & 400937105002901 & Replicate & 1,230 & 1,720 & 1,481 & -- & -- & -- \\
\hline M4 & 400937105002901 & \%difference & 26 & 31 & 35 & -- & -- & -- \\
\hline M9 & 401011105084701 & Replicate & -- & -- & -- & 210 & 203 & 265 \\
\hline M9 & 401011105084701 & $\%$ difference & -- & -- & -- & 9 & 12 & 1 \\
\hline $\mathrm{T} 8$ & 400928105003401 & Replicate & -- & -- & -- & 795 & 747 & 810 \\
\hline $\mathrm{T} 8$ & 400928105003401 & \%difference & -- & -- & -- & 13 & 10 & 12 \\
\hline-- & -- & Dialysis blank & $<125$ & 126 & $<125$ & $<165$ & $<165$ & $<165$ \\
\hline-- & -- & Trip blank & $<125$ & 166 & $<125$ & $<165$ & $<165$ & $<165$ \\
\hline
\end{tabular}




\section{References Cited}

Baxter, G.T., and Stone, M.D., 1995, Fishes of Wyoming: Cheyenne, Wyo., Wyoming Game and Fish Department, $290 \mathrm{p}$.

Becker, G.C., 1983, Fishes of Wisconsin: Madison, Wis., University of Wisconsin Press, 1,052 p.

Beckman, W.C., 1952, A guide to the fishes of Colorado: Boulder, Colo., University of Colorado Museum Leaflet 11, $110 \mathrm{p}$.

Behnke, R.J., 1992, Native trout of Western North America: Bethesda, Md., American Fisheries Society, Monograph 6, $275 \mathrm{p}$.

Bestgen, K.R., 1989, Distribution and notes on the biology of Phoxinus eos (Cyprinidae) in Colorado: Southwestern Naturalist, v. 34, p. 225-231.

Bestgen, K.R., Fausch, K.D., and Riley, S.C., 1991, Rediscovery of a relict southern-population of lake chub, Couesius plumbeus, in Colorado: Southwestern Naturalist, v. 36, p. 125-127.

Bestgen, K.R., Zelasko, K.A., and Compton, R.I., 2003, Environmental factors limiting suckermouth minnow Phenacobius mirabilis populations in Colorado: Fort Collins, Colorado State University, Larval Fish Laboratory Contribution 136, 83 p.

Cancalosi, J.J., 1981, Fishes of the Republican River basin in Colorado: Fort Collins, Colorado State University, Department of Zoology and Entomology, M.S. thesis, 87 p.

Cockerell, T.D.D., 1908, Fishes of the Rocky Mountain region: University of Colorado Studies, v. 5, p. 159-178.

Cross, F.B., and Collins, J.T., 1995, Fishes in Kansas (2d ed.): Lawrence, University of Kansas Museum of Natural History, Public Education Series No. 14, 315 p.

Dawley, R.M., Schultz, R.J., and Goddard, K.A., 1987, Clonal reproduction and polyploidy in unisexual hybrids of Phoxinus eos and Phoxinus neogaeus (Pisces: Cyprinidae): Copeia, v. 1987, p. 275-283.

Edmunds, G.F. and McCafferty, W.P., 1984, Ephemera compar-An obscure Colorado burrowing mayfly (Ephemeroptera: Ephemeridae): Entomological News, v. 95 , p. $196-188$.

Ellis, M.M., 1914, Fishes of Colorado: University of Colorado Studies, v. 11, p. 1-136.
Fausch, K.D., and Bestgen, K.R., 1996, Ecology of fishes indigenous to the Central and Southwestern Great Plains, in Knopf, F.L., and Samson, F.B., eds., Ecology and conservation of Great Plains vertebrates: New York, Springer-Verlag, Inc., p. 131-166.

Goddard, K.A., Megwinoff, O., Wessner, L.L., Giaimo, F., 1998, Confirmation of gynogenesis in Phoxinus eosneogaeus (Pisces: Cyprinidae): Journal of Heredity, v. 89, p. 151-157.

Hendricks, L.J., 1950, The fishes of Boulder County, Colorado: Boulder, University of Colorado, M.S. thesis, 55 p.

Herrmann, S.J., Ruiter, D.E., and Unzicker, J.D., 1986, Distribution and records of Colorado Trichoptera: Southwestern Naturalist, v. 31, p. 421-457.

Huckins, J.N., Tubergen, M.W., and Manuweera, G.K., 1990, Semipermeable membrane devices containing model lipid-A new approach to monitoring the availability of lipophilic contaminants and estimating their bioconcentration potential: Chemosphere, v. 20, p. 533-552.

Hunter, Chris, 1997, Fishes of special concern, an update: Montana Outdoors, November/December, p. 26-27.

Jordon, D.S., 1891, Report of explorations in Colorado and Utah during the summer of 1889 , with an account of the fishes found in each of the river basins examined: U.S. Fish Commission Bulletin, v. 9, p. 1-40.

Juday, C., 1904, Fishes of Boulder County: University of Colorado Studies, v. 2, p. 113-114.

Juday, C., 1905, A list of fishes collected in Boulder County, Colorado, with a description of a new species of Leucisus: United States Bureau Fisheries Bulletin, v. 24, p. 225-227.

Kilpatrick, F.A., 1970, Dosage requirements for slug injections of Rhodamine BA and WT dyes: U.S. Geological Survey Professional Paper 700-B, p. 250-253.

Kolpin, D.W., Furlong, E.T., Meyer, M.T., Thurman, E.M., Zaugg, S.D., Barber, L.B., and Buxton, H.T., 2002, Pharmaceuticals, hormones, and other organic wastewater contaminants in United States streams, 1999-2000-A national reconnaissance: Environmental Science and Technology, v. 36, no. 6, p. 1,202-1,211.

Kondratieff, B.C., and Baumann, R.W., 2002, A review of the stoneflies of Colorado with description of a new species of Capnia (Plecoptera: Capniidae): Transactions of the American Entomological Society, v. 128, p. 385-401.

Li, H.W., 1968, Fishes of the South Platte River Basin: Fort Collins, Colorado State University, M.S. thesis, 67 p. 
Litke, D.W., and Kimbrough, R.A., 1998, Water-quality assessment of the South Platte River Basin, Colorado, Nebraska, and Wyoming-Environmental setting and water quality of fixed sites, 1993-1995: U.S. Geological Survey Water-Resources Investigations Report 97-4220, 61 p.

Lynch, J.D., 1988, Habitat utilization by an introduced fish, Gambusia affinis, in Nebraska (Actinopterygii: Poecilidae): Transactions of the Nebraska Academy of Science, v. 16, p. 63-67.

Markus, H.C., 1934, Life history of the blackhead minnow (Pimephales promelas): Copeia, v. 3, p. 116-122.

McCafferty, W.P., 2001, Status of some historically unfamiliar American mayflies (Ephemeroptera): Pan-Pacific Entomologist, v. 77, p. 210-218.

McCafferty, W.P., Durfee, R.S., and Kondratieff, B.C., 1993, Colorado mayflies (Ephemeroptera)—An annotated inventory: Southwestern Naturalist, v. 38, p. 252-274.

McMurry, L.M., Oethinger, M., and Levy, S.B., 1998, Overexpression of marA, soxS, or acrAB produces resistance to triclosan in laboratory and clinical strains of Escherichia coli: FEMS Microbiology Letters, v. 166, no. 2, p. 305-309.

Meffe, G.K., 1985, Predation and species replacement in American southwestern fishes, a case study: Southwestern Naturalist, v. 116, p. 1-11.

Missouri Natural Heritage Program (MNHP), 2006, Missouri species and communities of conservation concern checklist: Jefferson City, Missouri Department of Conservation, 58 p.

Moore, G.A., 1944, Notes on the early life history of Notropis girardi: Copeia, v. 4, p. 209-214.

Murk, A.J., Legler, J., Penison, M.S., Giesy, J.P., Vande Guchte, C., and Brouwer, A., 1996, Chemical activated luciferase gene expression (calux) - A novel in vitro bioassay for $\mathrm{AH}$ receptor active compounds in sediment and pore water: Fundamental and Applied Toxicology, v. 33, p. 149-160.

Needham, J.G., and Claassen P.W., 1925, A monograph of the Plecoptera or stoneflies of America north of Mexico: Entomological Society of North America, Thomas Say Foundation, v. 2, 397 p.

Nesler, T.P., Van Buren, Randy, Stafford, J.A., and Jones, Mark, 1997, Inventory and status of South Platte River native fishes in Colorado: Colorado Division of Wildlife, Final Report, 111 p.

Patton, T.M., 1997, Distribution and status of fishes in the Missouri River drainage in Wyoming-Implications for selecting conservation areas: Laramie, University of Wyoming, Ph.D. dissertation, 173 p.
Pflieger, W.L., 1997, The Fishes of Missouri: Jefferson City, Missouri Department of Conservation, $372 \mathrm{p}$.

Platania, S.P., Cummings, T.R., and Kehmeier, K.J., 1986, First verified record of the stonecat (Noturus flavus (Ictularidae) in the South Platte River system, Colorado, with special notes on an albinistic specimen: The Southwestern Naturalist, v. 31, p. 553-555.

Propst, D.L., 1982, Warmwater fishes of the Platte River Basin, Colorado; distribution, ecology, and community dynamics: Fort Collins, Colorado State University, Ph.D. dissertation, $283 \mathrm{p}$.

Propst, D.L., and Carlson, C.A., 1986, The distribution and status of warmwater fishes in the Platte River drainage, Colorado: The Southwest Naturalist, v. 31, p. 149-167.

Propst, D.L., and Carlson, C.A., 1989, Life history notes and distribution of the Johnny darter, Etheostoma nigrum (Percidae) in Colorado: The Southwest Naturalist, v. 34, p. 250-259.

Repsys, A.J., Applegate, R.L., Hales, D.C., 1976, Food and food selectivity of the black bullhead, Ictalurus melas, in Lake Poinsett, South Dakota: Journal of the Fisheries Research Board of Canada, v. 33, p. 768-775.

Ruddy, B.C., and Britton, L.J., 1989, Traveltime and reaeration of selected streams in the North Platte and Yampa River Basins, Colorado: U.S. Geological Survey Water-Resources Investigations Report 88-4205, 56 p.

Scheurer, J.A., and Fausch, K.D., 2003, Multiscale processes regulate brassy minnow persistence in a Great Plains river: Transactions of the American Fisheries Society, v. 132, p. $840-855$.

Schlosser, I.J., Doeringsfield, M.R., Elder, J.F., and Arqayus, L.F., 1998, Niche relationships of clonal and sexual fish in a heterogeneous landscape: Ecology, v. 79, p. 953-968.

Schmidt, K., 2006, Endangered, threatened, and special status fishes of North America: St. Paul, Minn., North American Native Fishes Association, version July 31, 2006, accessed August 15, 2006, at http://www.nanfa.org/bccconservation. shtml.

Schrader, L.H., 1989, Use of the Index of Biotic Integrity to evaluate fish communities in western Great Plains streams: Fort Collins, Colorado State University, M.S. thesis, 120 p.

Schreurs, R.M., Legler, J., Artola-Garicano, E., Sinnige, T.L., Lanser, P.H., Seinen, W., and Van Der Burg, B., 2004, In vitro and in vivo antiestrogenic effects of polycyclic musks in zebrafish: Environmental Science and Technology, v. 38, no. 4, p. 997-1,002. 
Thorpe, K.L., Hutchinson, T.H., Hetheridge, M.J., Scholze, M., Sumpter, J.P., and Tyler, C.R., 2001, Assessing the biological potency of binary mixtures of environmental estrogens using vitellogenin induction in juvenile rainbow trout (Oncorhynchus mykiss): Environmental Science and Technology, v. 35 , no. 12 , p. 2,476-2,481.

U.S. Geological Survey, variously dated, National Field Manual for the Collection of water-quality data: U.S. Geological Survey Techniques of Water-Resources Investigations, book 9, chaps. A1-A9, available online at http://pubs.water. usgs.gov/twri9A.

Ward, J.V., 1986, Altitudinal zonation in a Rocky Mountain stream: Archiv fuer Hydrobiologie-Supplementband, v. 74, no. 2, p. 133-199.

Wilson, B.A., Smith, V.H., Denoyelles, F., Larive, C.K., 2003, Effects of three pharmaceutical and personal care products on natural freshwater algal assemblages: Environmental Science and Technology, v. 37, no. 9, p. 1,713-1,719.

Wilson, J.F., Jr., Cobb, E.D., and Kilpatrick, F.A., 1986, Fluorometric procedures for dye tracing: U.S. Geological Survey Techniques of Water-Resources Investigations, book 3, chap. A12, 34 p.

Wiltzius, W.J., 1981, Compendium of introduction date and state and federal annual stocking of various fishes in Colorado, 1972-1978: Unpublished report, Colorado Division of Wildlife, Fort Collins, Colorado.

Woodling, John, 1985, Colorado's little fish, a guide to the minnows and other lesser known fishes in the State of Colorado: Denver, Colorado Division of Wildlife, $77 \mathrm{p}$.

Zaugg, S.D., Smith, S.G., Schroeder, M.P., Barber, L.B., and Burkhardt, M.R., 2002, Methods of analysis by the U.S. Geological Survey National Water-Quality LaboratoryDetermination of wastewater compounds by polystyrenedivinylbenzene solid-phase extraction and capillary-column gas chromatography/mass spectrometry: U.S. Geological Survey Water-Resources Investigations Report 01-4186, $37 \mathrm{p}$.

Zuellig, R.E., Kondratieff, B.C., and Hood, R.W., 2006, Studies on stoneflies (Plecoptera) of Colorado with eastern faunal affinities, including a new state record of the midwestern salmonfly, Pteronarcys pictetii Hagen (Plecoptera: Pteronarcyidae): Proceedings of the Entomological Society of Washington, v. 108, p. 335-340. 


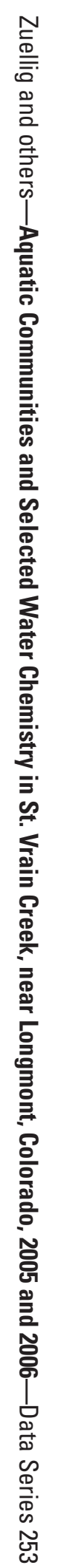

9 Printed on recycled paper 